\title{
HCLIM38: a flexible regional climate model applicable for different climate zones from coarse to convection-permitting scales
}

\author{
Danijel Belušić $^{1}$, Hylke de Vries ${ }^{2}$, Andreas Dobler ${ }^{3}$, Oskar Landgren ${ }^{3}$, Petter Lind ${ }^{1}$, David Lindstedt ${ }^{1}$, \\ Rasmus A. Pedersen ${ }^{4}$, Juan Carlos Sánchez-Perrino ${ }^{5}$, Erika Toivonen ${ }^{6}$, Bert van Ulft $^{2}$, Fuxing Wang ${ }^{1}$, Ulf Andrae $^{1}$, \\ Yurii Batrak $^{3}$, Erik Kjellström ${ }^{1}$, Geert Lenderink ${ }^{2}$, Grigory Nikulin ${ }^{1}$, Joni-Pekka Pietikäinen ${ }^{6, a}$, \\ Ernesto Rodríguez-Camino $^{5}$, Patrick Samuelsson ${ }^{1}$, Erik van Meijgaard ${ }^{2}$, and Minchao $\mathrm{Wu}^{1}$ \\ ${ }^{1}$ Swedish Meteorological and Hydrological Institute (SMHI), Norrköping, Sweden \\ ${ }^{2}$ Royal Netherlands Meteorological Institute (KNMI), De Bilt, the Netherlands \\ ${ }^{3}$ Norwegian Meteorological Institute (MET Norway), Oslo, Norway \\ ${ }^{4}$ Danish Meteorological Institute (DMI), Copenhagen, Denmark \\ ${ }^{5}$ Agencia Estatal de Meteorología (AEMET), Madrid, Spain \\ ${ }^{6}$ Finnish Meteorological Institute (FMI), Helsinki, Finland \\ ${ }^{a}$ now at: Climate Service Center Germany (GERICS), Helmholtz-Zentrum Geesthacht, Germany
}

Correspondence: Danijel Belušić (danijel.belusic@smhi.se)

Received: 24 May 2019 - Discussion started: 15 July 2019

Revised: 12 February 2020 - Accepted: 19 February 2020 - Published: 20 March 2020

\begin{abstract}
This paper presents a new version of HCLIM, a regional climate modelling system based on the ALADINHIRLAM numerical weather prediction (NWP) system. HCLIM uses atmospheric physics packages from three NWP model configurations, HARMONIE-AROME, ALARO and ALADIN, which are designed for use at different horizontal resolutions. The main focus of HCLIM is convectionpermitting climate modelling, i.e. developing the climate version of HARMONIE-AROME. In HCLIM, the ALADIN and ALARO configurations are used for coarser resolutions at which convection needs to be parameterized. Here we describe the structure and development of the current recommended HCLIM version, cycle 38 . We also present some aspects of the model performance.

HCLIM38 is a new system for regional climate modelling, and it is being used in a number of national and international projects over different domains and climates ranging from equatorial to polar regions. Our initial evaluation indicates that HCLIM38 is applicable in different conditions and provides satisfactory results without additional region-specific tuning.

HCLIM is developed by a consortium of national meteorological institutes in close collaboration with the ALADINHIRLAM NWP model development. While the current
\end{abstract}

HCLIM cycle has considerable differences in model setup compared to the NWP version (primarily in the description of the surface), it is planned for the next cycle release that the two versions will use a very similar setup. This will ensure a feasible and timely climate model development as well as updates in the future and provide an evaluation of long-term model biases to both NWP and climate model developers.

\section{Introduction}

Regional climate models (RCMs) are currently used at a variety of spatial scales and model grid resolutions. Since the main motivation of using RCMs is to add value compared to global climate models (GCMs) by downscaling over a limited-area domain, the resolution of RCMs is several times higher than that of GCMs (e.g. Rummukainen, 2010). The added value, expressed as e.g. higher-order statistics, comes from the improved resolution of both regional physiography and atmospheric processes. The GCM resolution is typically $\mathrm{O}(100 \mathrm{~km})$, while RCMs use resolutions of $\mathrm{O}(10 \mathrm{~km})$ (e.g. Taylor et al., 2012; Jacob et al., 2014). At the same time, there is evidence that $\mathrm{O}(10 \mathrm{~km})$ is too coarse for resolving some important physical processes and a growing 
demand for even higher-resolution climate information by end users. Building on the development and usage of numerical weather prediction (NWP) and research models at resolutions of $\mathrm{O}(1 \mathrm{~km})$, and with the increase in available computational resources, climate simulations are increasingly being performed at those very high resolutions (e.g. Ban et al., 2014; Prein et al., 2015; Kendon et al., 2017; Coppola et al., 2018; Lenderink et al., 2019). An important conceptual change occurs between the resolutions of $\mathrm{O}(10 \mathrm{~km})$ and $\mathrm{O}(1 \mathrm{~km})$, at which the parameterizations of deep convection that are used at $\mathrm{O}(10 \mathrm{~km})$ or coarser resolutions are typically not employed at $\mathrm{O}(1 \mathrm{~km})$. The reason for the latter lies in the fact that the most important deep convection processes occur at scales of $\mathrm{O}(1 \mathrm{~km})$ or larger, and therefore the models at those resolutions - also having nonhydrostatic dynamics - should be able to resolve them. Consequently, climate models at resolutions of $\mathrm{O}(1 \mathrm{~km})$ are often referred to as convection-permitting regional climate models (CPRCMs). This still leaves a subset of smaller-scale convection features that need to be parameterized, which is usually done using a shallow convection parameterization. An alternative approach is to use scale-aware convection parameterizations that can adjust their effects based on the fraction of resolved convection in a model grid box (e.g. Gerard et al., 2009). Despite the extensive experience with such modelling systems for NWP and research purposes, there are additional conceptual and computational challenges when climate simulations are considered. Here we present the new version (cycle 38) of the HARMONIE-Climate (HCLIM hereafter; Lindstedt et al., 2015; Lind et al., 2016) modelling system, aimed at regional climate simulations on convection-permitting scales. Because the step from GCM to CPRCM resolution is still too large for direct nesting (e.g. Matte et al., 2017), there is a need for an intermediate model grid between GCMs and CPRCMs. HCLIM has options for this as described below.

HCLIM cycle 38 (HCLIM38) has been developed and maintained by a subset of national meteorological institutes from the HIRLAM consortium: AEMET (Spain), DMI (Denmark), FMI (Finland), KNMI (the Netherlands), MET Norway and SMHI (Sweden). HCLIM38 is the new recommended version with considerable changes and improvements compared to the older versions. It is currently being used in a number of projects, some of which are large collaborative activities (e.g. the H2020 European Climate Prediction system - EUCP, https:// www.eucp-project.eu/, last access: 18 March 2020; the CORDEX Flagship Pilot Study (FPS) on convection (Coppola et al., 2018); the ELVIC CORDEX FPS on climate extremes in the Lake Victoria Basin, http://www.cordex. org/endorsed-flagship-pilot-studies/, last access: 18 March 2020).

The purpose of this paper is to describe the HCLIM38 modelling system and the available model configurations, as well as to provide initial insight into some aspects of their performance. HCLIM38 is closely related to the documented
ALADIN-HIRLAM NWP modelling system, and therefore this paper focuses on the features that distinguish the climate modelling system from its NWP counterpart. Extensive evaluations of the different HCLIM38 model configurations and for different regions will be presented in separate studies.

\section{Modelling system description}

\subsection{HCLIM structure, terminology and experiment setup}

HCLIM is a regional climate model based on the NWP model configuration and scripting system called HARMONIEAROME, which is a part of the ALADIN-HIRLAM (see Table 1) NWP modelling system (Lindstedt et al., 2015; Bengtsson et al., 2017; Termonia et al., 2018). ALADINHIRLAM is a limited-area model based on the code that is shared with the global models IFS and ARPEGE. The ALADIN-HIRLAM model consists of four configurations, namely ALADIN, ALARO, AROME and HARMONIEAROME (Table 1). HARMONIE is a scripting system developed and used by HIRLAM countries for operational NWP applications. All the above-mentioned ALADINHIRLAM model configurations are available in the HARMONIE scripting system, but only the specific configuration of AROME (HARMONIE-AROME) is officially supported, developed and used in HIRLAM NWP applications (Bengtsson et al., 2017).

The HCLIM climate model development is based on the HARMONIE system. The HARMONIE-AROME model configuration is designed for convection-permitting scales and is used with nonhydrostatic dynamics, which is the primary focus of HCLIM development. The model configurations ALADIN and ALARO are also used in HCLIM applications, typically for coarser resolutions with hydrostatic dynamics. Since HCLIM includes these three different model configurations, it is necessary to specify which configuration is used for a given application. Together with specifying the cycle used (cycle 38 in this paper), this results in the final terminology that is used in these projects: HCLIM38-AROME, HCLIM38-ALADIN or HCLIM38-ALARO.

As seen above, HCLIM versions are called cycles to remain consistent with the NWP model configurations. The cycle numbering of model versions is inherited from the ECMWF, who are the first in the chain of model releases (e.g. Bauer et al., 2013). There are 26 countries in Europe who base their operational NWP on the ALADIN-HIRLAM system, although with different configurations and flavours (e.g. Bengtsson et al., 2017; Termonia et al., 2018; Frogner et al., 2019). The HCLIM community strives to keep up with the NWP cycle releases, but due to the different timescales and applications of climate simulations, the smaller development community, and other various reasons there can be skipped cycles, so gaps in cycles are expected in HCLIM ter- 
Table 1. List of main acronyms related to the HCLIM system.

\begin{tabular}{|c|c|c|}
\hline Acronym & Full name & Notes \\
\hline HIRLAM & $\begin{array}{l}\text { High Resolution Limited Area } \\
\text { Model }\end{array}$ & $\begin{array}{l}\text { Collaboration between } 10 \text { national meteorological services (Bengtsson et al., } \\
\text { 2017); also the name of the limited-area model which is being phased out and } \\
\text { has been replaced with the HIRLAM-ALADIN NWP model, in particular with } \\
\text { the HARMONIE-AROME configuration }\end{array}$ \\
\hline ALADIN & $\begin{array}{l}\text { Aire Limitée Adaptation } \\
\text { Dynamique Développement } \\
\text { International }\end{array}$ & $\begin{array}{l}\text { Collaboration between } 16 \text { national meteorological services; also the name of } \\
\text { the limited-area model using ARPEGE physics (Termonia et al., 2018) }\end{array}$ \\
\hline HARMONIE & $\begin{array}{l}\text { HIRLAM-ALADIN Research on } \\
\text { Mesoscale Operational NWP in } \\
\text { Euromed }\end{array}$ & $\begin{array}{l}\text { The HARMONIE NWP system consists of the HIRLAM-specific AROME } \\
\text { model configuration (Bengtsson et al., 2017), together with a scripting sys- } \\
\text { tem and set of tools for building, running, and validating and verifying the } \\
\text { HARMONIE-AROME model }\end{array}$ \\
\hline ARPEGE & $\begin{array}{l}\text { Action de Recherche Petite } \\
\text { Échelle Grande Échelle }\end{array}$ & Global model developed at Météo-France (Courtier et al., 1991) \\
\hline IFS & Integrated Forecasting System & $\begin{array}{l}\text { Global model developed at the European Centre for Medium-Range Weather } \\
\text { Forecasts (ECMWF; Bauer et al., 2013) }\end{array}$ \\
\hline AROME & $\begin{array}{l}\text { Applications of Research to } \\
\text { Operations at Mesoscale }\end{array}$ & $\begin{array}{l}\text { Convection-permitting model developed at Météo-France with HIRLAM } \\
\text { contributions (Seity et al., 2011; Bengtsson et al., 2017) }\end{array}$ \\
\hline ALARO & ALADIN-AROME & $\begin{array}{l}\text { Limited-area model applicable also in the convection "grey zone" } \\
\text { (Termonia et al., 2018) }\end{array}$ \\
\hline SURFEX & Surface Externalisée & $\begin{array}{l}\text { Surface scheme shared by all HCLIM model configurations } \\
\text { (Masson et al., 2013) }\end{array}$ \\
\hline
\end{tabular}

minology. For example, the HCLIM release before cycle 38 that was described in detail was cycle 36 (Lindstedt et al., 2015), and the next target cycle is 43.

The current and historical versions of the code are archived using Apache Subversion (SVN; https://subversion. apache.org/, last access: 18 March 2020), thus providing access to a specific code revision at any time. Code revision numbers for model experiments are stored in their home directory. The model documentation for each cycle is archived at the HIRLAM website (https://hirlam.org/trac/ wiki/HarmonieSystemDocumentation, last access: 18 March 2020), which is accessible to registered users. Configuration information for the experiments analysed here can be found in the Supplement. The domain definition file (Harmonie_domains.pm) together with a configuration file (config_exp.h) include all information about an experiment setup. The options used to modify the configuration file for the different experiments are listed in Table S1 in the Supplement.

\subsection{HCLIM model configurations}

Unlike the majority of limited-area models, a common characteristic of all model configurations in the HCLIM system is that they use a bi-spectral representation for most prognostic variables, with semi-implicit time integration and a semi-Lagrangian advection scheme. The details of the dy- namics are described in Bengtsson et al. (2017) and Termonia et al. (2018). The three different model configurations available in HCLIM are designed for different spatial resolutions (Fig. 1). A comprehensive description of the HARMONIE-AROME physics and NWP setup is presented in Bengtsson et al. (2017). Consequently, we report only the main features and the differences between HCLIM38AROME and the HARMONIE-AROME NWP system. The other two configurations, ALADIN and ALARO, are detailed in Termonia et al. (2018), and here we describe the differences in HCLIM38. It is important to note that Bengtsson et al. (2017) describe the canonical model configurations for HARMONIE-AROME, and Termonia et al. (2018) describe those for ALADIN and ALARO. Canonical model configurations form a subset of all possible configurations, which is thoroughly validated for use in a certain NWP context. The configurations presented here differ from the canonical model configurations. One important difference is the surface model, which is shared between all the three HCLIM model configurations. It is based on the surface model SURFEX (Surface Externalisée), with different options activated for climate applications compared to the NWP setup as described below. 


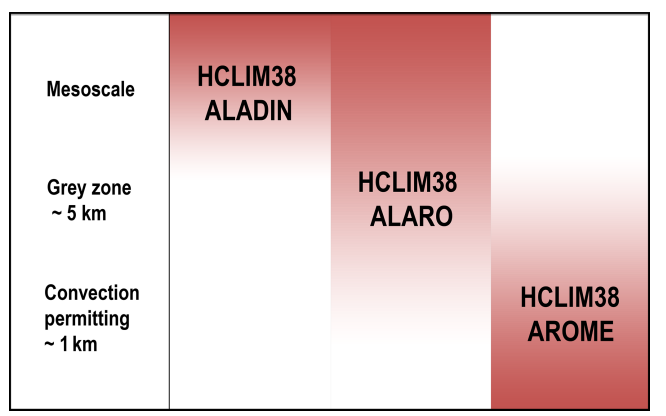

Figure 1. Intended horizontal grid resolutions for the three model configurations available in HCLIM38 (based on Termonia et al., 2018).

\subsubsection{SURFEX}

SURFEX is an externalized surface modelling system that parameterizes all components of the surface (Masson et al., 2013). It uses a tiling approach to represent subgrid surface heterogeneity, with the surface split into four tiles: continental natural surfaces, sea, inland water and urban areas. The SURFEX tiling approach assumes that the interaction of each surface tile with the overlying atmosphere is completely independent of the other tiles present in the grid box. Continental natural surfaces are further divided into subtiles or patches, accounting for different vegetation characteristics within a grid box. The number of patches can be chosen between 1 and 12, but for simplicity it is typically set to 2 in HCLIM38, representing open land and forest.

The NWP setup of HARMONIE-AROME (Bengtsson et al., 2017) uses simplified surface processes like the forcerestore approach in the soil (Boone et al., 1999) and the composite snow scheme by Douville et al. (1995). Such simplified physics are appropriate for short timescales in combination with surface data assimilation, but for climate timescales more sophisticated surface physics are required that can represent e.g. long soil memory and proper snow characteristics. The default SURFEX version in HCLIM38 was 7.2 (Masson et al., 2013). However, the state of the more sophisticated surface physics options in v7.2 was not considered to be adequate for HCLIM purposes. Therefore, a stepwise upgrade of SURFEX was performed. First, v7.2 was replaced by v7.3, and then the land-surface physics scheme in v7.3 (ISBA) was replaced by the corresponding scheme from v8.1. The list of SURFEX parameterizations and the related references used in HCLIM38 is given in Table 2. These include e.g. the ISBA multi-layer soil diffusion option (ISBA-DIF) with soil organic carbon taken into account and a 12-layer explicit snow scheme (ISBA-ES). For a proper simulation of temperature in deep and large lakes the inland water (rivers and lakes including any ice cover) is simulated by FLake. In HCLIM38, FLake uses the lake depth obtained from the Global Lake Data Base (GLDB; Kourzeneva et al., 2012) and is initialized from a climatology of lake profiles which vary over time and space. HCLIM38 implements the same SICE model as in the NWP setup to simulate the sea ice temperature. The difference in HCLIM38 is that the sea surface temperature and sea ice concentration are updated together with the lateral boundaries to capture their long-term variation. The urban tile is parameterized by the Town Energy Balance model (TEB; Masson, 2000), which is used only at convection-permitting resolutions.

The land cover and soil properties are obtained from the ECOCLIMAP version 2.2 database at $1 \mathrm{~km}$ resolution (Faroux et al., 2013) and the Food and Agriculture Organization database (FAO, 2006), respectively. SURFEX is fully coupled to the atmospheric model, receiving atmospheric forcing over each patch and tile and returning grid-averaged values (heat and momentum fluxes, etc.).

\subsubsection{ALADIN}

ALADIN is the default choice in HCLIM38 for simulations with grid spacing close to or larger than $10 \mathrm{~km}$. It is the limited-area version of the global model ARPEGE, from which it inherits all dynamics and physics options. The version of ALADIN available in HCLIM38 corresponds to the one used in NWP, with the dynamics and physics options listed in Table 3 and described in Termonia et al. (2018). The difference in HCLIM38 is only in the surface parameterizations, which are more suitable for climate simulations as described above. HCLIM38-ALADIN is predominantly used as a hydrostatic model with a convection parameterization, so it is not envisaged for use at grid spacings much smaller than $10 \mathrm{~km}$. Therefore, there is a gap, usually termed "the grey zone" for convection, between the grid spacing of $10 \mathrm{~km}$ and the convection-permitting scales with grid spacing smaller than $4 \mathrm{~km}$. HCLIM 38 simulations with grid spacing within the grey zone should be avoided if possible.

\subsubsection{ALARO}

ALARO has been designed to also operate in the convection grey zone (Fig. 1; Termonia et al., 2018). Unlike traditional moist convection parameterizations, the Modular Multiscale Microphysics and Transport scheme (3MT; Gerard et al., 2009) addresses the fact that the size of convective cells becomes significant compared to the model grid spacing as the resolution increases. This allows for great flexibility in applying the model, which is highly desirable in climate applications. Therefore, ALARO was the default choice in HCLIM36 (Lindstedt et al., 2015). However, the coupling of ALARO with SURFEX as used in HCLIM38 resulted in evaporation from oceans that is too weak in low latitudes, causing considerable underestimation of atmospheric moisture content and consequently a lack of precipitation in long climate simulations. Similar issues have not been observed at high latitudes (Toivonen et al., 2019), imply- 
Table 2. SURFEX parameterizations used in HCLIM38.

\begin{tabular}{lll}
\hline Model component & Parameterization & References \\
\hline Sea and ocean & $\begin{array}{l}\text { Exchange Coefficients from Unified } \\
\text { Multi-campaigns Estimates (ECUME) }\end{array}$ & $\begin{array}{l}\text { Belamari (2005) and } \\
\text { Belamari and Pirani (2007) }\end{array}$ \\
\hline Sea ice & Simple ICE (SICE) & Batrak et al. (2018) \\
\hline Soil & $\begin{array}{l}\text { ISBA-DIF explicit multi-layer scheme } \\
\text { (14 layers to 12 m of depth) }\end{array}$ & $\begin{array}{l}\text { Boone (2000) and } \\
\text { Decharme et al. (2011) }\end{array}$ \\
\hline $\begin{array}{l}\text { Vegetation and } \\
\text { processes }\end{array}$ & $\begin{array}{l}\text { Jarvis-based stomatal resistance; soil organic } \\
\text { carbon for soil thermal and hydrological } \\
\text { properties }\end{array}$ & $\begin{array}{l}\text { Noilhan and Planton (1989) and } \\
\text { Decharme et al. (2016) }\end{array}$ \\
\hline Subgrid hydrology & Subgrid runoff, Horton runoff & $\begin{array}{l}\text { Dümenil and Todini (1992) and } \\
\text { Decharme and Douville (2006) }\end{array}$ \\
\hline Snow & ISBA-ES explicit snow scheme (12 layers) & $\begin{array}{l}\text { Boone and Etchevers (2001) and } \\
\text { Decharme et al. (2016) }\end{array}$ \\
\hline Town & Town Energy Balance (TEB) & Masson (2000) \\
\hline Inland water & Freshwater lake model (FLake) & Mironov et al. (2010) \\
\hline
\end{tabular}

ing that ALARO can be used there. However, it is not the default option in HCLIM38 because the modelling system should be applicable at all latitudes. The detailed ALARO description in Termonia et al. (2018) refers to a newer version called ALARO1. HCLIM38 uses an older version, ALARO0, with some updates from a development version of ALARO1 and as such does not correspond to any canonical model configuration. Specifically, in HCLIM38-ALARO the radiation scheme ACRANEB from ALARO0 was replaced by an early version of ACRANEB2 used in ALARO1. Since it is based on ALARO0, HCLIM38-ALARO still uses the pseudo-prognostic turbulent kinetic energy (pTKE) turbulence scheme (Geleyn et al., 2006), which has been replaced by TOUCANS (Ďurán et al., 2014) in ALARO1. At the same time, HCLIM38-ALARO is coupled to SURFEX, making this configuration different from the NWP model configuration. The full list of used parameterizations and references is given in Table 3.

\subsubsection{AROME}

HCLIM38-AROME is a nonhydrostatic CPRCM based on the HARMONIE-AROME NWP model configuration (Table 3), but with different surface model options that are more suitable for climate applications as described above. It is the recommended option in HCLIM38 for simulations at convection-permitting scales. AROME is the main focus of HCLIM development due to the recognized need of the participating institutes for a CPRCM. As such, it is becoming the backbone of convection-permitting regional climate projections for a number of European countries.

There is no deep convection parameterization in AROME, so it can only be used at convection-permitting resolu- tions, which are generally considered grid spacings smaller than $4 \mathrm{~km}$. This implies that for downscaling low-resolution GCMs, it is currently not possible to use the same model configuration at intermediate scales of $\mathrm{O}(10 \mathrm{~km})$ and convectionpermitting scales of $\mathrm{O}(1 \mathrm{~km})$. As described above, the intermediate scales in the current setup are typically simulated by HCLIM38-ALADIN. This is the preferred option because the two model configurations share the same surface model. In this case the soil state in HCLIM38-AROME is initialized in a consistent way, the only difference being the resolution change. This could help decrease the soil spin-up time, which is typically 1 year, provided that the precipitation climatology is similar between the two model configurations. However, HCLIM38-AROME can also be used with other climate models at the lateral boundaries.

HCLIM38-AROME uses a shallow convection parameterization based on the eddy diffusivity mass-flux framework (EDMFm; de Rooy and Siebesma, 2008; Bengtsson et al., 2017). The default choice for the turbulence parameterization is the scheme called HARMONIE with RACMO Turbulence (HARATU; Lenderink and Holtslag, 2004; Bengtsson et al., 2017), even though the CBR scheme (Cuxart et al., 2000) with the diagnostic mixing length from Bougeault and Lacarrere (1989) is available as well. HARATU and CBR mostly differ in the formulation of length scales and values of constants (Bengtsson et al., 2017). A one-moment microphysics scheme, ICE3 (Pinty and Jabouille, 1998; Lascaux et al., 2006), is used, with additional modifications for cold conditions called OCND2 (Müller et al., 2017). The cloud fraction is determined using a statistical scheme (Bechtold et al., 1995). Similarly to ALADIN, the radiation scheme is a simplified version of the scheme used at 
Table 3. Parameterizations and dynamics of the three model configurations as used in HCLIM38.

\begin{tabular}{|c|c|c|c|}
\hline $\begin{array}{l}\text { Parameterization } \\
\text { and dynamics }\end{array}$ & ALADIN & ALARO & AROME \\
\hline Dynamics & Hydrostatic (Temperton et al., 2001) & Hydrostatic (Temperton et al., 2001) & Nonhydrostatic (Bénard et al., 2010) \\
\hline Radiation & $\begin{array}{l}\text { RRTM_LW, SW6 (Mlawer et al., } \\
\text { 1997; Iacono et al., 2008; Fouquart } \\
\text { and Bonnel, 1980) }\end{array}$ & $\begin{array}{l}\text { ACRANEB2 (Mašek et al., 2016; } \\
\text { Geleyn et al., 2017) }\end{array}$ & $\begin{array}{l}\text { RRTM_LW, SW6 (Mlawer et al., } \\
\text { 1997; Iacono et al., 2008; Fouquart } \\
\text { and Bonnel, 1980) }\end{array}$ \\
\hline Turbulence & $\begin{array}{l}\text { CBR (Cuxart et al., 2000); mixing } \\
\text { length from Bougeault and Lacar- } \\
\text { rere (1989) }\end{array}$ & pTKE (Geleyn et al., 2006) & $\begin{array}{l}\text { HARATU (Lenderink and Holtslag, } \\
\text { 2004; Bengtsson et al., 2017) }\end{array}$ \\
\hline Microphysics & $\begin{array}{l}\text { Lopez (2002); Bouteloup et al. } \\
\text { (2005) }\end{array}$ & Lopez (2002) & $\begin{array}{l}\text { ICE3-OCND2 (Pinty and Jabouille, } \\
\text { 1998; Müller et al., 2017) }\end{array}$ \\
\hline $\begin{array}{l}\text { Shallow } \\
\text { convection }\end{array}$ & $\begin{array}{l}\text { KFB (Bechtold et al., 2001; Bazile } \\
\text { et al., 2012) }\end{array}$ & $\begin{array}{l}\text { Pseudo shallow convection parame- } \\
\text { terization (Geleyn, 1987) }\end{array}$ & $\begin{array}{l}\text { EDMFm (de Rooy and Siebesma, } \\
\text { 2008; Bengtsson et al., 2017) }\end{array}$ \\
\hline Deep convection & Bougeault (1985) & 3MT (Gerard et al., 2009) & - \\
\hline Clouds & Smith (1990) & Xu and Randall (1996) & Bechtold et al. (1995) \\
\hline $\begin{array}{l}\text { Orographic } \\
\text { wave drag }\end{array}$ & Catry et al. (2008) & Catry et al. (2008) & - \\
\hline
\end{tabular}

the ECMWF, described in Mascart and Bougeault (2011). The six-spectral-band shortwave radiation (SW6) is based on Fouquart and Bonnel (1980). A rapid radiative transfer model (RRTM) with 16 spectral bands is used for longwave radiation (Mlawer et al., 1997; Iacono et al., 2008). Monthly aerosol climatologies are provided by Tegen et al. (1997).

\subsection{Differences from Météo-France-CNRM climate models}

Since the names and model configurations are similar for HCLIM and Météo-France-CNRM climate models (CNRMALADIN and CNRM-AROME), we briefly describe some of the main differences between the latest versions of the HCLIM and CNRM models (see Table 3 for the parameterization schemes used in HCLIM38).

CNRM-ALADIN has been used in climate mode for more than 10 years (e.g. Radu et al., 2008; Colin et al., 2010). The latest version of ALADIN-Climate, version 6.3 (CNRMALADIN63; Daniel et al., 2019), differs from HCLIM38ALADIN in certain physical parameterizations. Firstly, the parameterizations for convection and clouds are different: CNRM-ALADIN63 includes a Prognostic Condensates Microphysics and Transport (PCMT) scheme (Piriou et al., 2007; Guérémy, 2011) for dry, shallow and deep convection, as well as a cloud scheme based on probability distribution functions (PDFs) by Ricard and Royer (1993). Orographic wave drag is parameterized by Déqué et al. (1994) along with Catry et al. (2008), which is used in HCLIM38-ALADIN. A climate version of SURFEX 8 (Decharme et al., 2019) is used as the land-surface modelling platform. It is also worth not- ing that when CNRM-ALADIN is coupled with other components of the Earth system, such as aerosols (Drugé et al., 2019), oceans and rivers (Sevault et al., 2014; Darmaraki et al., 2019), the model is called CNRM-RCSM (regional climate system model) even if the schemes for the atmosphere are the same as described above.

The CNRM-AROME41t1 model is currently used for climate research (Coppola et al., 2018). This latest version 41t1 uses cycle 41 of AROME, which is described in Termonia et al. (2018) for the NWP system, while the previous climate version was based on cycle 38 (e.g. Fumière et al., 2019). The differences from HCLIM38-AROME are as follows. The ICE3 scheme is used for microphysics without the OCND2 modification, and the PMMC09 scheme is used for shallow convection (Pergaud et al., 2009). Parameterizations by Pergaud et al. (2009) are also used for clouds in addition to Bechtold et al. (1995), which is used in HCLIM38AROME. The surface scheme is version 7.3 of SURFEX (Masson et al., 2013). In addition, CNRM-AROME41t1 includes the COMAD correction for overestimated precipitation and unrealistic divergent winds in the vicinity of convective clouds (Malardel and Ricard, 2015).

\subsection{Differences from HCLIM36}

The version of the latest operational HCLIM was cycle 36, described thoroughly by Lindstedt et al. (2015). In the new version, cycle 38 , the model system has undergone considerable changes in the parameterizations, physical packages used and target resolutions. The main differences are briefly 
described here for easier distinction between the different cycles.

In HCLIM38, ALADIN is the default model configuration that should be used for coarser-resolution applications and as the intermediate model when the target horizontal grid size is on the kilometre scale or below. In the previous cycles the default configuration was ALARO. The other main difference is the update of the surface modelling platform going from SURFEX v5 to a blend of SURFEX $v 7$ and $v 8$ in order to improve and enable more accurate land-related processes. The main improvements in SURFEX processes in cycle 38 are summarized in the following. Similarly to the differences from the current NWP configuration (see Sect. 2.2.1), a 14layer soil diffusion scheme together with a 12-layer explicit snow scheme are activated, with soil organic carbon taken into account. The inland water is simulated by the lake model FLake. The sea ice model SICE is employed for oceans, and it uses updated sea ice concentrations and sea surface temperatures with the same frequency as the lateral boundaries. The combined effects from the differences in model configurations lead to considerable improvement in the overall performance. For instance, the near-surface temperature is much closer to observations (Fig. S1a in the Supplement), mainly dependent on the utilization of the diffusion soil scheme together with the sea ice model. Also, the general precipitation pattern is largely improved, especially during the summer when the old configuration suffered from a very dry bias in eastern Europe (Fig. S1b). The smaller temperature biases can be related to smaller biases generally also found for radiation and surface heat fluxes in the new configuration (Fig. S2; regions defined in Lindstedt et al., 2015).

\section{Model performance}

The three configurations of HCLIM38 have been used over several different regions and climates. Since HCLIM38ALADIN is a limited-area version of the global model ARPEGE, the expectation is that it can be used in principle for any region on Earth. Consequently, the model is not tuned for specific regions. HCLIM38-ALARO has mostly been used in high latitudes where it performs well. HCLIM38AROME has been successfully used on domains ranging from the tropics and different mid-latitude regions to the Arctic, indicating that it can be used for various climates without additional modifications. Here we illustrate the capability and performance of HCLIM38 with a number of selected examples for different domains and model configurations. More in-depth evaluation studies are left for separate papers for each of the domains analysed below as well as for other domains (e.g. Crespi et al., 2019; Toivonen et al., 2019; Wu et al., 2019). The model experiments are summarized in Table S1.

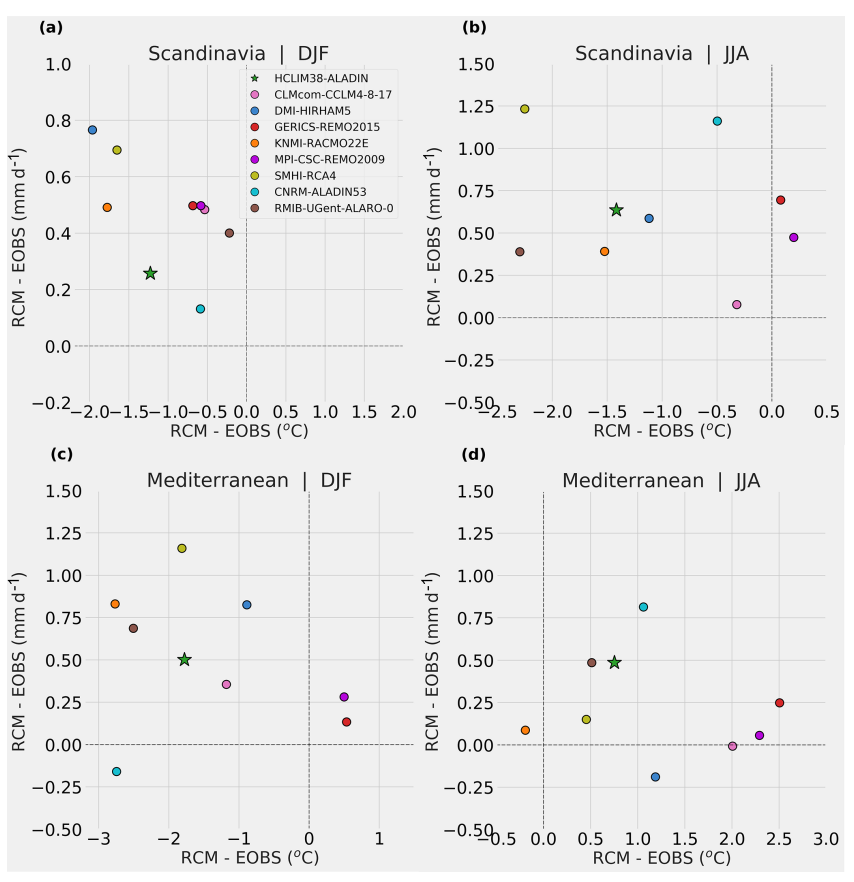

Figure 2. Difference between RCMs and E-OBS of near-surface temperature ( $x$ axis) and daily precipitation ( $y$ axis) for $(\mathbf{a}, \mathbf{c})$ DJF and (b, d) JJA averaged over 1999-2008 for two PRUDENCE European subregions: $(\mathbf{a}, \mathbf{b})$ Scandinavia and $(\mathbf{c}, \mathbf{d})$ the Mediterranean.

\subsection{Performance over European domains}

\subsubsection{Pan-Europe}

Here, HCLIM38 is compared to other state-of-the-art RCMs over Europe (Kotlarski et al., 2014). HCLIM38-ALADIN has been run with a couple of domain configurations similar to the EURO-CORDEX domain with a horizontal grid spacing of $12 \mathrm{~km}$ (EURO-CORDEX uses $0.11^{\circ}$ resolution; Kotlarski et al., 2014). The boundary conditions were taken from the ERA-Interim reanalysis (Dee et al., 2011). Differences in daily mean near-surface air temperature (T2m) and precipitation between nine RCMs (including HCLIM38ALADIN) and E-OBS version 17 gridded observations (Haylock et al., 2008) were calculated for the Prediction of Regional scenarios and Uncertainties for Defining European Climate change risks and Effects (PRUDENCE) regions in Europe (Christensen and Christensen, 2007) based on a common 10-year period (1999-2008). RCMs were interpolated to the E-OBS $0.25^{\circ}$ regular grid prior to comparison. Figure 2 shows the results for the winter (DJF) and summer (JJA) seasons for the Scandinavia and Mediterranean regions. The results for these two regions, which are representative for most PRUDENCE regions, show that HCLIM38-ALADIN is generally colder and wetter than E-OBS. However, it can be seen that most of the other RCMs are also wetter than E-OBS and that HCLIM38-ALADIN is generally in close agreement with E-OBS in winter (Fig. S1). Larger differ- 


\section{Precipitation bias [mm month $\left.{ }^{-1}\right]$}

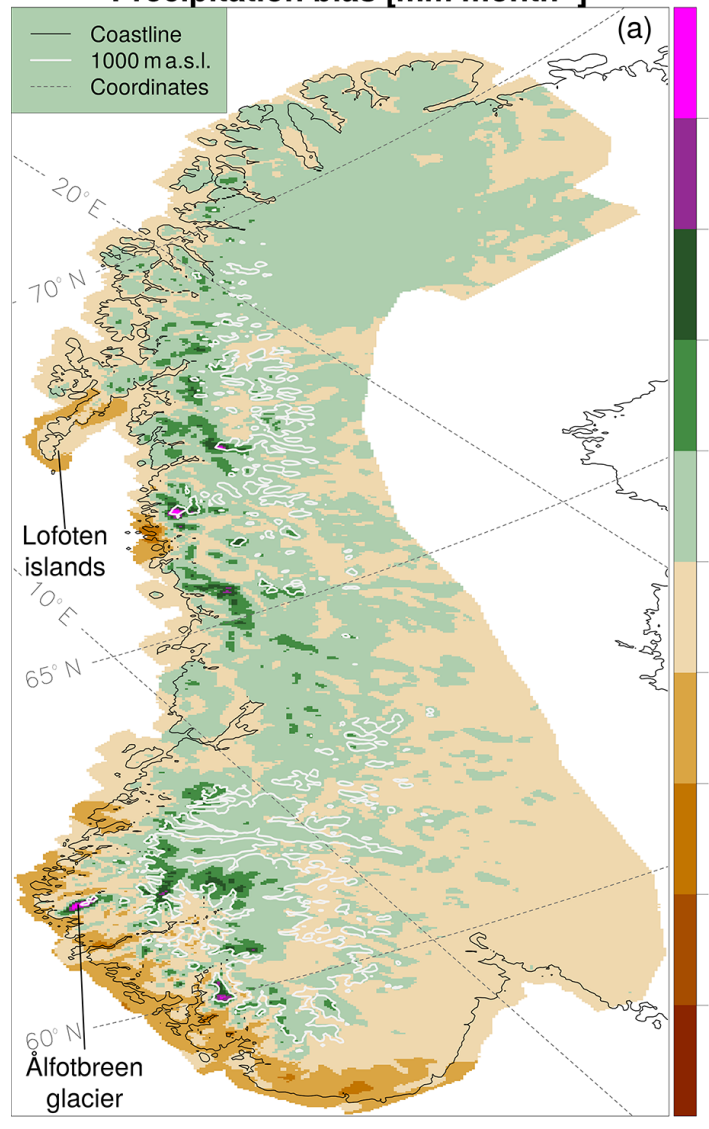

Precipitation bias [\%]

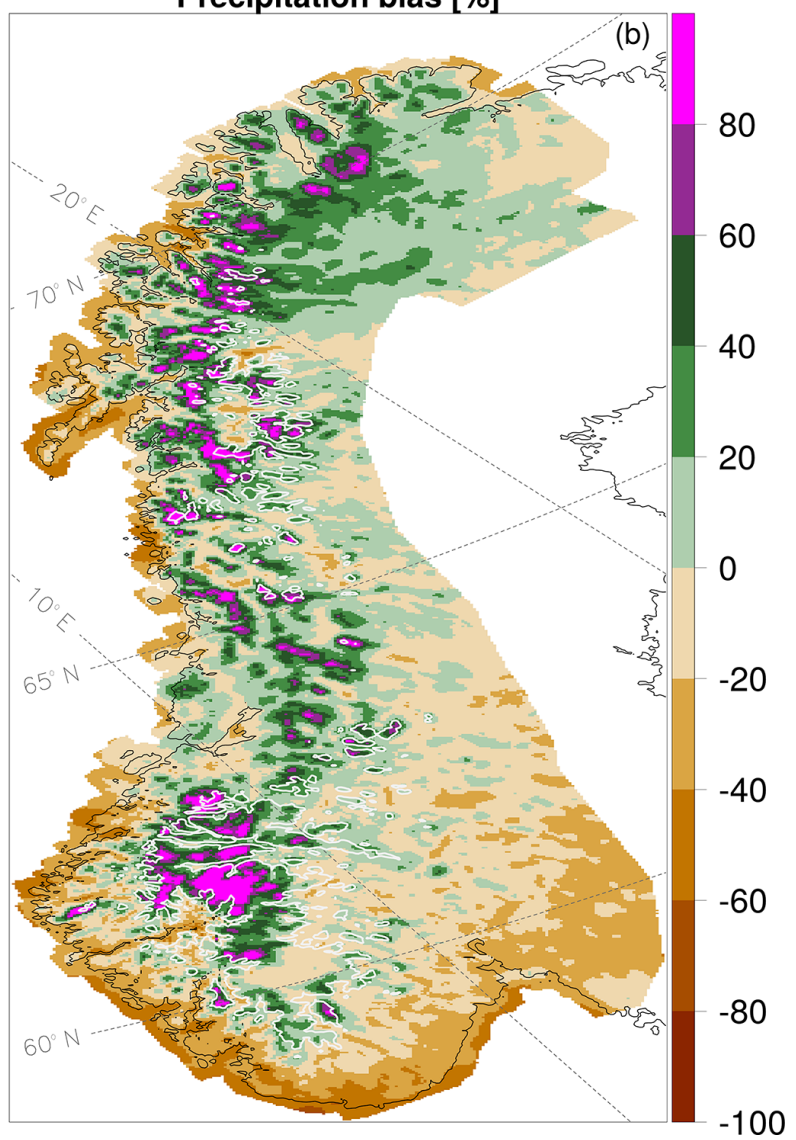

Figure 3. (a) Absolute and (b) relative precipitation differences between HCLIM38-AROME and seNorge for the time period 2004-2015.

ences are mostly seen in connection with mountainous regions. This is also the case for temperature in winter. For example, the negative temperature bias in winter over Scandinavia is mostly associated with $2-4{ }^{\circ} \mathrm{C}$ lower values over the Scandinavian mountains. At lower altitudes the temperature is much better represented by the model (Fig. S1). Still, the cold bias in HCLIM38-ALADIN is present throughout most seasons and is spatially widespread over Europe. The reason for this systematic bias is not yet known and needs to be further investigated. Finally, we note that for the two versions of ALADIN, HCLIM38-ALADIN consistently shows lower temperatures than CNRM-ALADIN53 for large parts of Europe, apart from western and southern Europe. The precipitation differences compared to E-OBS, however, are generally smaller in HCLIM38-ALADIN. We conclude that the performance of HCLIM38-ALADIN over Europe, in terms of multi-year means of $\mathrm{T} 2 \mathrm{~m}$ and precipitation, is generally within the range of the performance of other RCMs used within EURO-CORDEX.

\subsubsection{Norway}

Due to its complex topography and the exposure of the western coast to large amounts of moisture transported over the North Atlantic, Norway is a challenging area for which to provide accurate climate model simulations and constitutes an ideal testing environment. To evaluate the performance of the HCLIM38-AROME model in this region at convectionpermitting scales, it was run at $2.5 \mathrm{~km}$ for an area covering Norway, parts of Finland, Sweden and Russia for the time period 2004-2016 (Crespi et al., 2019), downscaling the ERAInterim reanalysis. An intermediate HCLIM38-ALARO simulation at $24 \mathrm{~km}$ resolution was used to avoid an excessively large jump across the boundaries (results not analysed here).

For the evaluation over Norway, we use the gridded observation dataset seNorge v2.1 for precipitation (Lussana et al., 2018a) and temperature (Lussana et al., 2018b); seNorge provides daily precipitation and temperature back to 1957 at a grid resolution of $1 \mathrm{~km}$. The dataset has a special focus on providing meteorological input for snow and hydrological simulations at the regional or national level. Thus, it not only covers the Norwegian mainland but also neighbouring areas in Finland, Sweden and Russia to include regions impacting 
T2m bias $\left[{ }^{\circ} \mathrm{C}\right]$

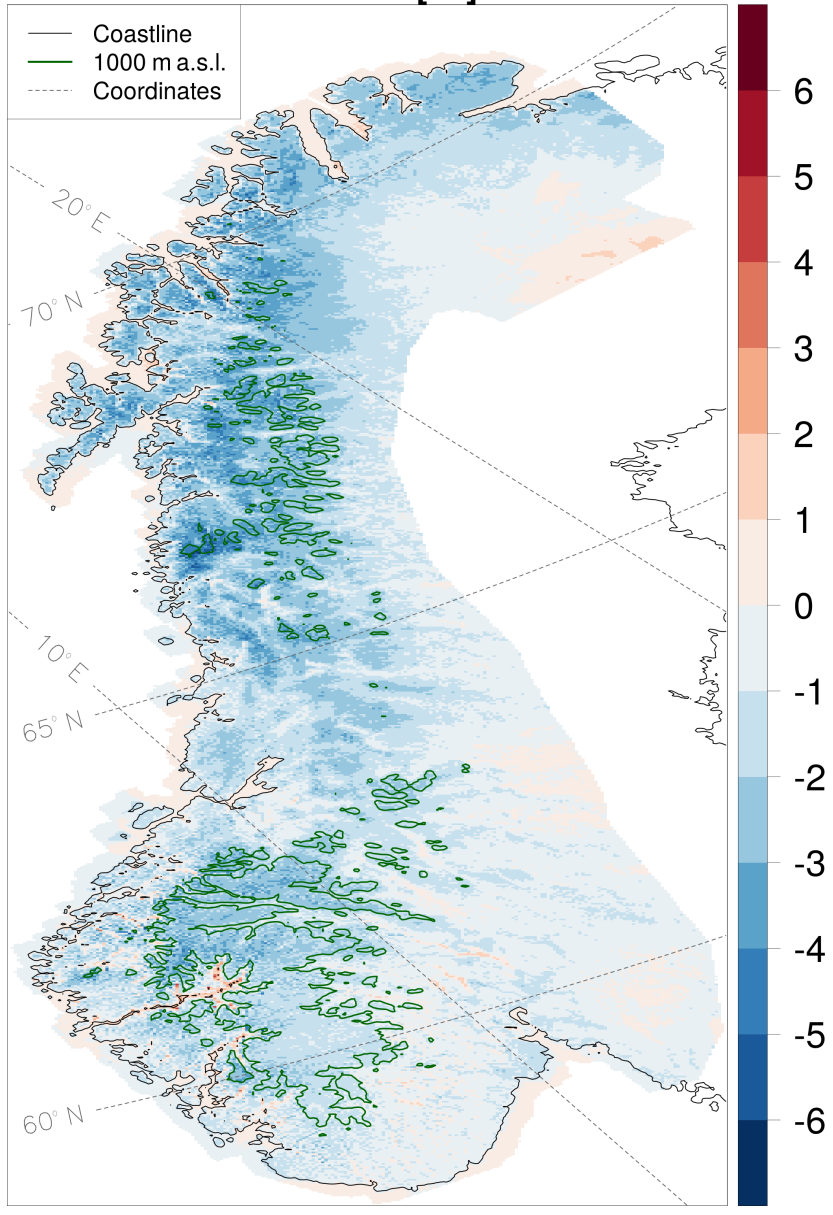

Figure 4. Annual temperature differences between HCLIM38AROME and seNorge for the time period 2004-2015.

the Norwegian water balance. The station data are retrieved from MET Norway's climate database and the European Climate Assessment and Dataset (ECA\&D, Klein Tank et al., 2002). More details on the spatial interpolation schemes and the dataset in general are given in Lussana et al. (2018a, b).

Note that gridded observation datasets in remote regions of Norway should be considered with caution. For certain regions of Norway it may be difficult to judge the quality of the seNorge data due to the inhomogeneous station distribution. While terrain height can reach $2000 \mathrm{~m}$ or more, most stations are located below $1000 \mathrm{~m}$. There is also a difference in the station density between the southern and northern parts, with a higher density in the south of Norway (Lussana et al., 2019). For precipitation, Lussana et al. (2018a) have shown that seNorge 2 gives values that are too low in very data-sparse areas. For temperature, an evaluation in Lussana et al. (2018b) has shown that the interpolation actually yields unbiased estimates, with the exception of a warm bias for very low temperatures, and that the grid point estimates show a precision of 0.8 to $2.4^{\circ} \mathrm{C}$.
Generally, HCLIM38-AROME shows an underestimation of precipitation at the south-western coast and over the Lofoten islands, while precipitation in the mountains is overestimated (Fig. 3). The largest differences appear in autumn and winter (not shown). Values for precipitation that are too high can also be seen for spring and summer over centralsouthern Norway. Similar differences have been shown by Müller et al. (2017) for the Nordic operational NWP setup of HARMONIE-AROME and by Crespi et al. (2019) comparing the HCLIM38-AROME precipitation data to observed precipitation.

However, despite the biases found in simulated precipitation, the HCLIM38-AROME data have been successfully used by Crespi et al. (2019) together with in situ observations to obtain improved monthly precipitation climatologies over Norway. The high-resolution model data are used to provide a spatial reference field for an improved interpolation of the in situ observations where there are no measurements. The result is not a purely bias-corrected RCM dataset, nor are the in situ observations corrected. The approach is used to overcome the uneven station network over Norway, and it was shown that the simulated precipitation could be used to improve the climatologies significantly, especially over the most remote regions. For instance, for the wettest area in Norway around Alfotbreen, the combined data result in a mean annual precipitation of over $5700 \mathrm{~mm}$. Measurements of snow accumulation during the winter half-year together with estimates of drainage from river basins (performed by the Norwegian Water Resources and Energy Directorate) indicate mean annual precipitation amounts over $5500 \mathrm{~mm}$ in the area (Teigen, 2005). The purely observation-based estimates are almost $2000 \mathrm{~mm}$ lower.

The combined dataset shows systematically higher precipitation values than seNorge for the observation-sparse mountainous regions. As the seNorge dataset is likely to underestimate precipitation in these areas (Lussana et al., 2018a) we expect this to be an improvement. However, whether this is true still needs to be verified e.g. by the use of hydrological simulations (Lussana et al., 2019).

Annual mean temperature in HCLIM38-AROME is generally lower than in seNorge, but the differences are small (Fig. 4). Averaged over the whole area, HCLIM38-AROME is about $1{ }^{\circ} \mathrm{C}$ colder than seNorge. The differences range from about -7 to $4^{\circ} \mathrm{C}$, but for most of the area, the temperature differences are below $\pm 2{ }^{\circ} \mathrm{C}$ and larger biases are restricted to the mountains. All seasons show similar patterns to the annual biases with the largest differences in the mountains, but the general increase in the bias with altitude is most pronounced in winter (not shown).

\subsubsection{Summer precipitation over the Netherlands and Germany}

Better resolving summertime precipitation is arguably the most important reason for running CPRCMs and a pri- 
(a) Apr-Sep diurnal cycle for fldmax(precip)

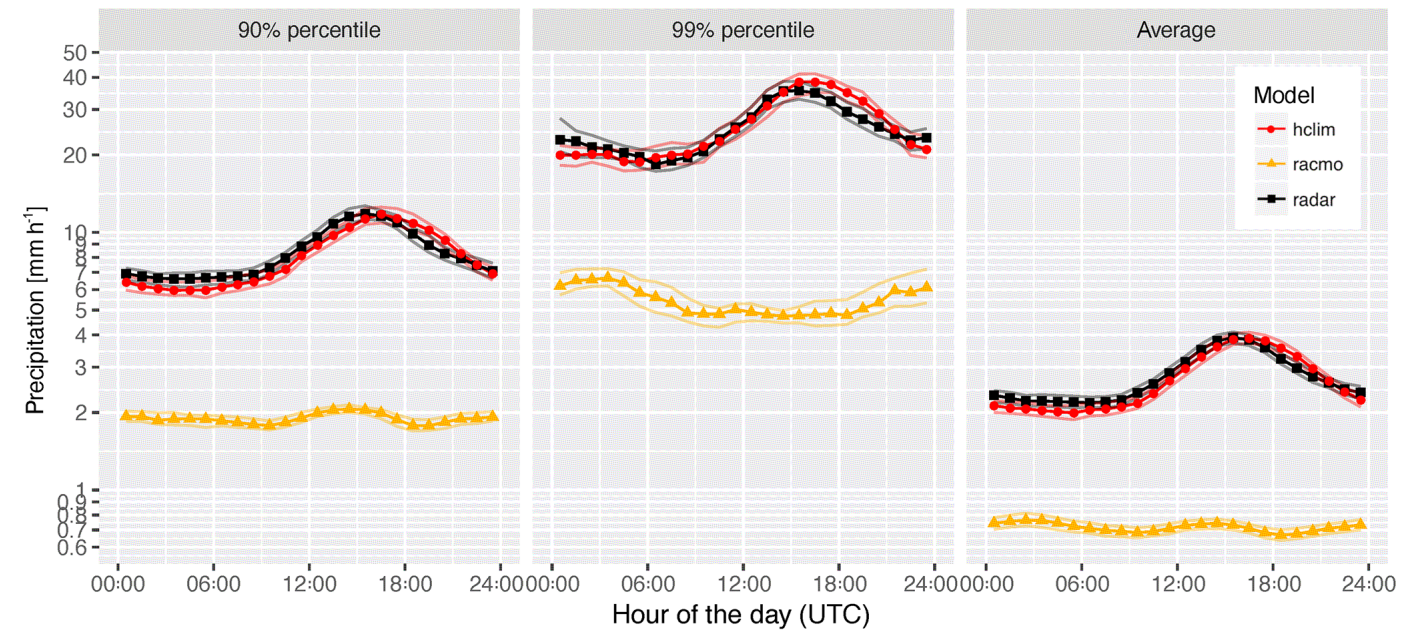

(b) Apr-Sep exceedance statistics for fldmax (precip)

(c) Apr-Sep exceedance statistics for fldmean (precip)
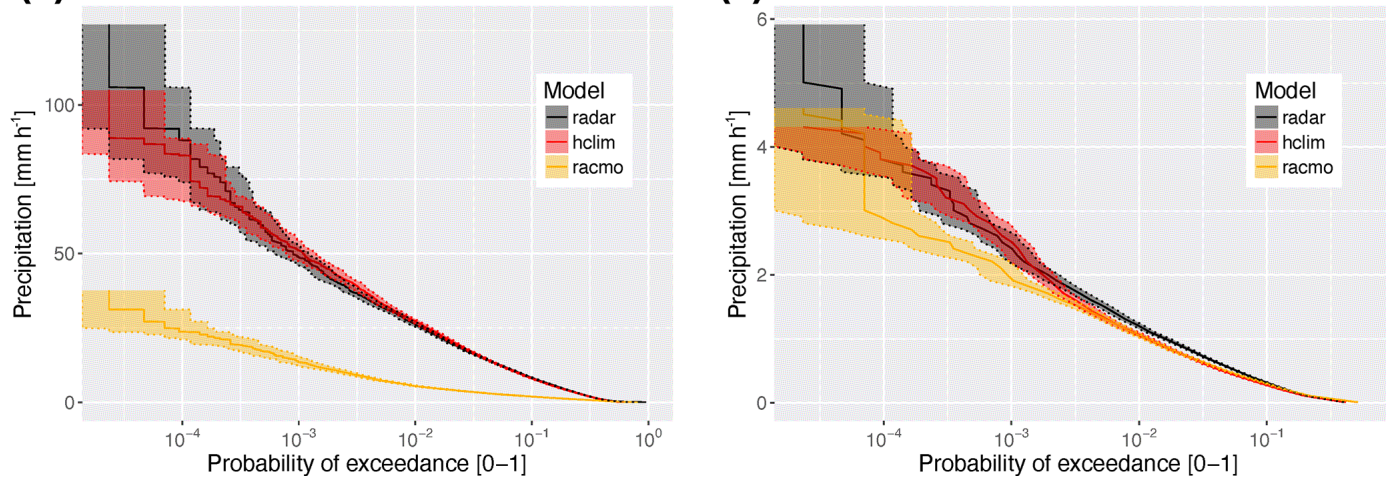

Figure 5. (a) Diurnal cycle of two high percentiles (90th and 99th percentile) and the average of the FLDMAX hourly precipitation distribution (April-September) for radar, CPRCM and driving RCM. Probability of exceedance (April-September) for (b) the FLDMAX precipitation and (c) the FLDMEAN precipitation (note the difference in the vertical scale). Confidence levels (95\%) obtained using bootstrapping are indicated by shading.

mary variable for which we anticipate added value compared to coarser-resolution RCM models. In this section we discuss statistics of summer precipitation in two 10-year ERA-Interim forced climate simulations for the period 20002009, carried out with HCLIM38-AROME at convectionpermitting scales. The focus will be on the summer half-year (April-September). The first CPRCM experiment (E1) conducted by KNMI receives lateral boundary conditions from the RCM RACMO2 (van Meijgaard et al., 2012). In the second experiment (E2) conducted by SMHI, the host model is HCLIM38-ALADIN. Both host models are forced by ERAInterim. For both E1 and E2 the domain covers the panAlpine region as defined in the CORDEX FPS on convection (Coppola et al., 2018), but the E1 domain extends substantially further to the north-west, covering a large part of the North Sea. Output is compared to two types of observations: radar data (for the Netherlands) and rain gauges (for a part of Germany).
For the evaluation of the CPRCMs to rain radar over the Netherlands, we can only use output from E1 since the E2 domain does not cover the Netherlands. The radar data are an hourly gridded product $(2.4 \mathrm{~km}$ horizontal resolution) that has been calibrated against automatic and manual rain gauges (Overeem et al., 2009). Data from both the CPRCM (HCLIM38-AROME, $2.5 \mathrm{~km}$ ) and the RCM $\left(\mathrm{RACMO} 2,0.11^{\circ}\right)$ are put on the radar grid using nearestneighbour interpolation. Two statistics are studied. First, we look at hourly spatial precipitation maxima found within the Netherlands. We call this the hourly FLDMAX statistic. The analysis focuses on model performance at the grid scale, and here we expect to find added value. Note that in this formulation the FLDMAX does not account for the spatial extent of the precipitation, nor does it account for the possible existence of several convective clusters at the same hour. Secondly, we study the hourly FLDMEAN statistic (i.e. the hourly area-average precipitation). If a CPRCM outperforms its host model for the latter statistic, this is an example of 
(a) Apr-Sep diurnal cycle for fldmax (precip)

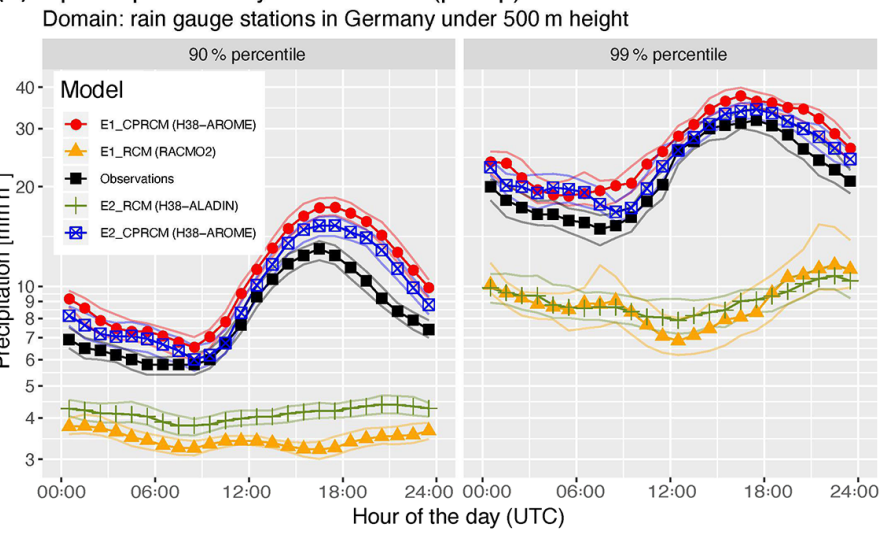

(b) Apr-Sep exceedance statistics for fldmax (precip)

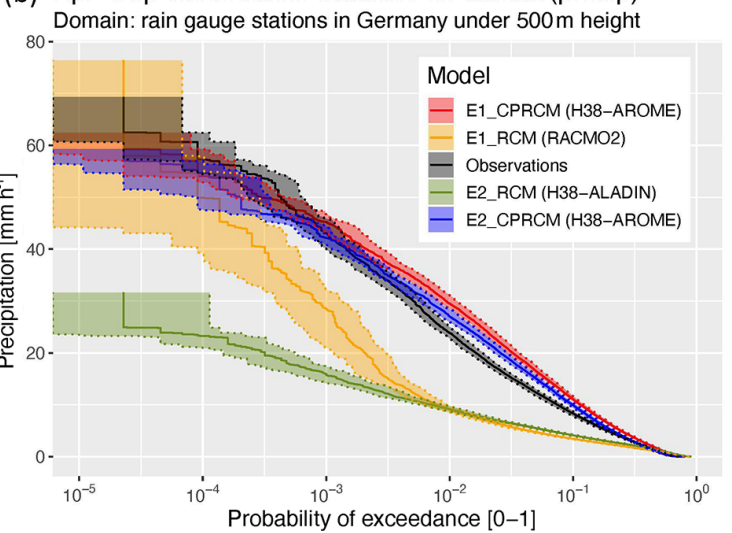

Figure 6. As in Fig. 5, but for the evaluation over low-lying $(<500 \mathrm{~m})$ German rain gauges. (a) Diurnal cycle of the 90th and 99th percentile of the FLDMAX precipitation. (b) Probability of exceedance (Apr-Sep) for the FLDMAX precipitation. Confidence levels (95\%) obtained using bootstrapping are indicated by shading. E1 and E2 denote two experiments with different modelling setups (see text for details).

upscale added value: the higher horizontal resolution also pays off at larger spatial scale. This is not guaranteed, especially not in winter, when precipitation is often caused by large-scale weather systems. Confidence intervals (95\%) are estimated using bootstrapping. The bootstrapping technique consists of constructing a large number of "synthetic" time series by resampling days from the original time series (sampling with replacement) and computing the target statistic for each of the resamples. This gives an empirical distribution for the target statistic, from which the confidence interval can be estimated. The resulting estimate is overconfident as it ignores time correlations.

We expect the largest benefits of using a high-resolution model at the finest scales, which cannot be reached by the non-CPRCM. This is confirmed for the Netherlands in Fig. 5a, which shows for each hour an estimate of the average and the 90th and 99th percentile of the FLDMAX precipitation; 3-hourly sliding windows are used to improve statistical robustness, and confidence bands were determined using bootstrap resampling on hourly basis. HCLIM38-AROME simulates the diurnal cycle very well. Although the diurnal cycle of HCLIM38-AROME is about an hour delayed with respect to the radar observations, it is much improved compared to RACMO2, which hardly shows signs of a diurnal cycle. Results for the winter half-year are qualitatively similar, but the amplitude of the daily cycle is much less pronounced (not shown). For the FLDMEAN statistic, the amplitude in the diurnal cycle is dampened, and RACMO2 and HCLIM38-AROME are generally more similar (not shown). Figure $5 \mathrm{~b}$ and $\mathrm{c}$ show the precipitation distributions as exceedance plots. The exceedance plots are computed by simple ordering of the FLDMAX or FLDMEAN data and inferring the empirical probability of a given value based on its order position. Not only at the grid scale (FLDMAX), but also at the largest spatial scale available (FLDMEAN, the Netherlands), HCLIM38-AROME generally outperforms RACMO2, especially for the larger precipitation amounts. It could be argued that a non-CPRCM cannot be expected to reproduce the radar-observed precipitation statistics because of its coarser resolution. For this reason, we have recomputed the statistics shown in Fig. 5 using the data that were re-gridded to the $12 \mathrm{~km} \mathrm{RCM}$ grid prior to computation. This upscaling to $12 \mathrm{~km}$ was done using simple conservative interpolation. Figure S3 shows that the differences between CPRCMs and RCMs remain qualitatively the same after upscaling to the RCM grid. Therefore, even at these spatial scales there is clear added value of the CPRCM.

For the evaluation of the CPRCMs over Germany, we compare E1 and E2 to hourly rain gauge data. As a proxy for the rain gauge location we use the nearest model grid point. In addition, we consider only stations that have an altitude lower than $500 \mathrm{~m}$ (see Fig. S4 for the rain gauges involved). Similarly to the evaluation done over the Netherlands, we use the FLDMAX and FLDMEAN approach in which the appropriate statistical operator is applied over the hourly data.

The differences between CPRCMs and RCMs for FLDMAX for Germany are similar to the results for the Netherlands presented above, with the CPRCM agreeing better with observations (Fig. 6). Note how similar the HCLIM38AROME simulations are, despite the rather different characteristics of their host model. Although the diurnal cycle is better represented by the CPRCMs, the modelled late afternoon peaks are too high. It appears that the overestimation of the peak is related to the elevation: if we constrain to the subset spanned by gauges at lower elevation, the CPRCMs agree better with the observations (not shown). The overestimation of intense precipitation $\left(10-40 \mathrm{~mm} \mathrm{~h}^{-1}\right)$ is consistent with the analysis of the UKMO and ETH-COSMO models in Berthou et al. (2018) for Germany. Similar to the results 
over the Netherlands, the differences between CPRCMs and RCMs are smaller for the FLDMEAN statistic (not shown).

\subsubsection{Summer precipitation over the Iberian Peninsula}

The Mediterranean region is characterized by a complex morphology due to the presence of many sharp orographic features: high mountain ridges surround the Mediterranean Sea on almost every side, the presence of distinct basins and gulfs, and islands and peninsulas of various sizes. These characteristics have important consequences on both sea and atmospheric circulations because they introduce large spatial variability and the presence of many subregional and mesoscale features (e.g. Lionello et al., 2006). Moreover, the Mediterranean region is considered to be a hotspot for climate change (e.g. Giorgi, 2006). It is frequently exposed to recurring droughts and torrential rainfall events, both of which are projected to become more frequent and/or intense as a result of future climate change. Therefore, it is an area where climate models have to be tested. In this study we focus on eastern Spain in summer (JJA) when precipitation events are scarce and mainly convective (e.g. Alhammoud et al., 2014). Our aim is to study the performance of HCLIM38 in representing convective precipitation in dry zones at high temporal and spatial resolution.

We compare results from two HCLIM38 simulations, one at high resolution with the AROME configuration and another at lower resolution with the ALADIN configuration, against hourly precipitation records. These are the experiments performed.

- AROME: 10 years (1990-1999), $2.5 \mathrm{~km}$ resolution, Iberian Peninsula

- ALADIN: 10 years (2005-2014), 12 km resolution, Europe

Both simulations were forced directly with ERA-Interim data at the boundaries. The simulations are compared with a dense set of around 500 automatic and manual rain gauges recording hourly precipitation that are distributed over eastern Spain (Fig. S5). These observations are extracted from the National Weather Data Bank of AEMET (Santos-Burguete, 2018, Chapter 9) and have been used in other studies of intense precipitation events (e.g. Khodayar et al., 2016; Riesco-Martín et al., 2014).

The selected period for observations is $2008-2018$ because hourly data from automatic stations started to be available in 2008. This period has 7 years of overlap with the HCLIM38-ALADIN simulation, but it does not overlap the HCLIM38-AROME simulation. We assume that the precipitation characteristics have not substantially changed in the last 30 years and that in two nearby 10 -year periods the mean statistics calculated from hourly precipitation are comparable. The assumption that rainfall characteristics are not dependent on the period analysed, when periods are not far from each other, will be verified below and has been shown in other studies (e.g. Brown et al., 2010).

Two aspects of summer (JJA) precipitation are studied: the timing of the maximum hourly precipitation within a day and the hourly intensity. At hourly scales we expect the convection-permitting nonhydrostatic physics (AROME) to better reproduce the precipitation characteristics compared to the hydrostatic physics (ALADIN). For the timing and intensity we calculate for each rain gauge the 10-year mean of the hour of maximum precipitation in a day and the corresponding hourly intensity, respectively. The same is calculated for the two models after interpolating the modelled precipitation to the nearest-neighbour observation. The 10year observation mean is subtracted from the 10-year model means to get the difference in every point. These differences for every location are pooled together, and PDFs of the timing differences and hourly intensity differences are obtained for AROME and ALADIN. Gaussian distributions are fitted to the PDFs with the same mean and variance for a clearer comparison.

Several hourly thresholds have been tested $(0,5,10,15$ and $20 \mathrm{~mm} \mathrm{~h}^{-1}$ ), filtering out hourly precipitation below each threshold. Finally, we use the threshold of $5 \mathrm{~mm} \mathrm{~h}^{-1}$ to remove periods with weak precipitation while keeping a sufficient number of events for robust statistics. The number of points fulfilling this condition is near 500 for AROME and around 400 for ALADIN.

The histograms of the differences of the hour of maximum precipitation and intensity between models and observations are shown in Fig. 7. The distributions of differences for both timing and intensity are centred at zero for HCLIM38-AROME, while they are shifted to negative values for HCLIM38-ALADIN. This indicates that the ALADIN physics underestimate both the timing and intensity of maximum hourly precipitation, while the convectionpermitting physics AROME are able to reproduce both realistically. In the case of timing the PDF of HCLIM38AROME is narrower, while HCLIM38-ALADIN shows a wider spread in the hour of maximum precipitation. For the intensity both models have similar spread.

Even though HCLIM38-ALADIN has 7 years of overlap with observations and HCLIM38-AROME has none, HCLIM38-AROME is closer to the observations. Therefore, it seems that the decadal variability in the distribution is sufficiently small to allow for a comparison between observations and simulations of different (but close) periods in this case.

In conclusion, the convection-permitting model HCLIM38-AROME shows a clear improvement in the representation of key characteristics of precipitation as exemplified by timing and hourly intensity compared to the hydrostatic model HCLIM38-ALADIN. While HCLIM38-ALADIN underestimates the mean values of both variables, HCLIM38-AROME shows very small biases for the threshold used $\left(>5 \mathrm{~mm} \mathrm{~h}^{-1}\right)$. In accordance with previous CPRCM studies (e.g. Ban et al., 2014; Berthou 


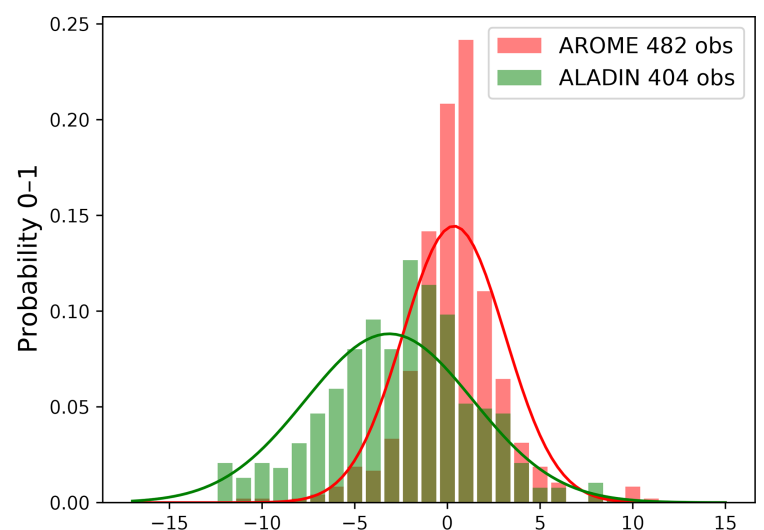

(a) Diff of hour of max pcp with obs

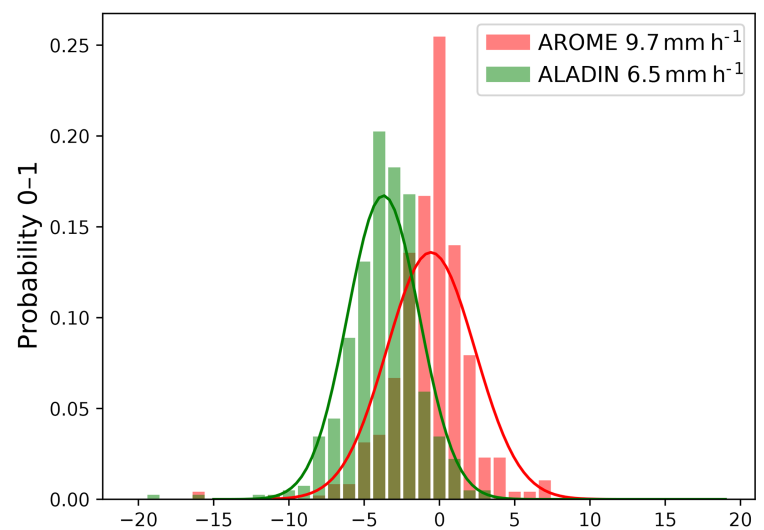

(b) Diff of hourly intensity with obs

Figure 7. Histograms of differences between models (HCLIMAROME $2.5 \mathrm{~km}$ and HCLIM-ALADIN $12 \mathrm{~km}$ ) and observations of the 10-year mean of (a) the hour of maximum precipitation and (b) the corresponding maximum hourly intensity for the hourly intensity threshold of $5 \mathrm{~mm} \mathrm{~h}^{-1}$. The legend shows (a) the number of stations used in the comparison for each of the models and (b) the mean intensity for each model. The mean intensity in observations is $10.2 \mathrm{~mm} \mathrm{~h}^{-1}$.

et al., 2018), the main reason for this improvement is that AROME explicitly resolves deep convection (Seity et al., 2011; Bengtsson et al., 2017), while HCLIM38-ALADIN parameterizes it.

\subsection{First simulations over the Arctic region}

The Arctic region is an excellent test bed for climate models. Interactions between the atmosphere, ocean and cryosphere are central in shaping the regional climate, and biases in the simulated climate will be greatly affected by the model's ability to capture the correct build-up and melt of snow and ice. Previous studies have indicated the challenges in simulating the Arctic climate and highlighted the fact that more detailed surface schemes and very high resolution may be needed to improve model performance in the Arctic and on Greenland (e.g. Ettema et al., 2010; Lucas-Picher et al., 2012; Rae et al., 2012; Noël et al., 2018).

HCLIM38 can run in a polar stereographic projection, which is ideal for the Arctic region. Here, we present the results from three HCLIM38 simulations, all forced by ERAInterim during the summer of 2014 over a domain covering the Arctic region and reaching $60^{\circ} \mathrm{N}$ across all longitudes. The simulations all use the default HCLIM38 setup and do not employ any type of nudging despite the large domain. The three experiments are the following.

\section{- ALARO24: HCLIM38-ALARO, 24 km resolution}

- ALADIN24: HCLIM38-ALADIN, 24 km resolution

- ALADIN12: HCLIM38-ALADIN, 12 km resolution

This ensemble allows for the assessment of (1) the performance of HCLIM38 compared to observed conditions, (2) the differences between identical simulations with ALARO and ALADIN physics, and (3) the impact of increased resolution (in ALADIN only).

The model performance is assessed over Greenland using in situ observations at 16 locations from the Programme for Monitoring of the Greenland Ice Sheet (PROMICE; van As et al., 2011; Fausto and van As, 2019), a network of automatic weather stations placed on the Greenland Ice Sheet. We assess the monthly and seasonal mean temperature in the model grid cells closest to the stations, which are mainly located in the ablation zone, i.e. the lower-elevation part of the ice sheet, which experiences melt during summer. To ensure a consistent bias assessment, the simulated temperatures have been corrected for the elevation difference between the station location and the model grid cell. Figure 8a shows seasonal (JJA) mean temperature in the model and the bias at the individual PROMICE stations, where the simulated temperature is adjusted using a lapse rate of $6.0^{\circ} \mathrm{C} \mathrm{km}^{-1}$ (based on observed summer conditions; Erokhina et al., 2017). Further, we have calculated the number of days on which these locations experience melt, here defined as nearsurface air temperature above $0^{\circ} \mathrm{C}$. This is evaluated using the Tmax, i.e. the daily maximum temperature experienced in a given grid cell on the time step scale (time steps are $10 \mathrm{~min}$ for ALARO24 and ALADIN24 and 5 min for ALADIN12). Here the simulated temperature is not lapse-ratecorrected; melt is chosen as an additional metric in order to assess the model representation of the cryospheric feedback processes that are central to the Arctic climate.

Compared to the driving ERA-Interim reanalysis data, all the HCLIM38 runs provide more detailed spatial patterns over complex terrain, such as in mountainous regions and on the slopes of the ice sheet. The comparison to the PROMICE observations reveals that all three configurations of HCLIM38 are generally colder and have lower average bias compared to the coarser ERA-Interim (approximately $80 \mathrm{~km}$ resolution). The PROMICE stations are all located on 
(a)

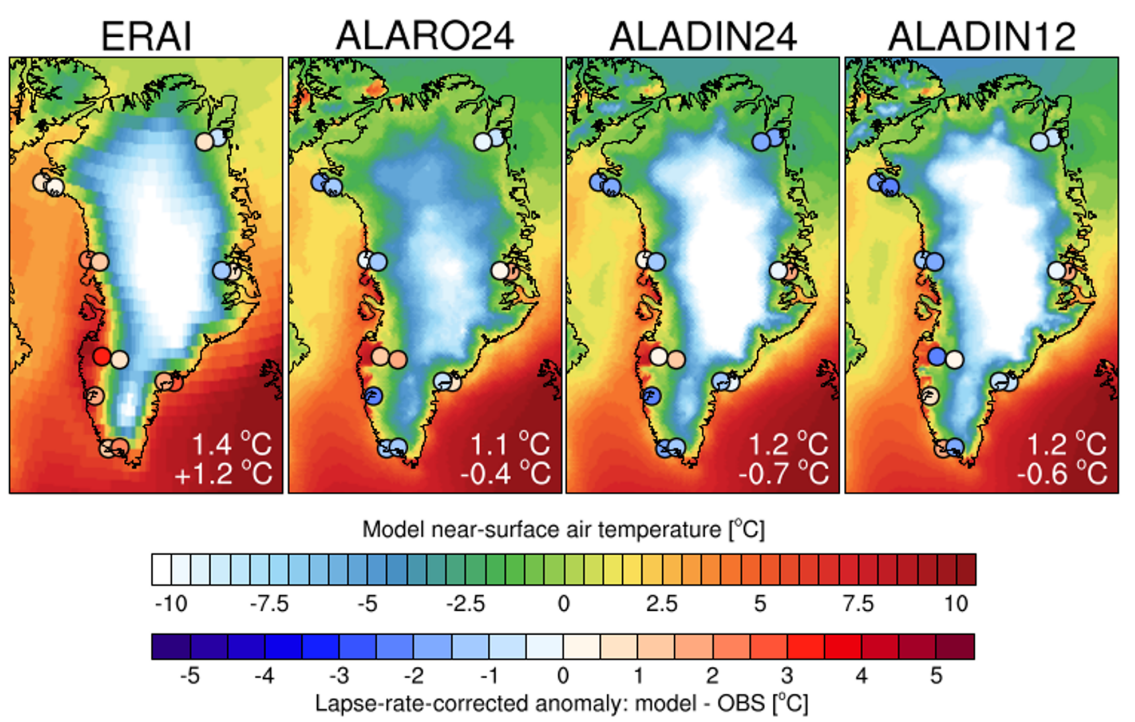

(b)

\begin{tabular}{|c|c|c|c|c|c|c|c|c|c|c|c|c|}
\hline KPC_U & -2 & -4 & -5 & 16 & 3 & 3 & 15 & 1 & -11 & 16 & 1 & 4 \\
\hline KPC_L & -6 & -3 & -12 & 8 & -2 & -6 & 7 & -4 & -22 & 8 & -3 & -5 \\
\hline THU_U & 11 & 0 & 11 & 14 & 0 & 0 & 10 & -4 & -6 & 7 & -6 & 3 \\
\hline THU_L & 5 & 0 & 8 & 9 & 0 & 6 & 9 & 0 & 8 & 1 & -6 & 0 \\
\hline UPE_U & -1 & 0 & 0 & 2 & 0 & 4 & 2 & 0 & 4 & -2 & 0 & -2 \\
\hline UPE_L & -2 & 0 & -3 & 0 & 0 & -2 & 0 & 0 & -2 & -3 & 0 & -4 \\
\hline SCO_U & -13 & -6 & -13 & -4 & 0 & -5 & -2 & -8 & -15 & -4 & -2 & -11 \\
\hline SCO_L & -10 & -4 & -12 & -4 & -1 & -9 & -3 & -8 & -16 & -7 & -3 & -14 \\
\hline KAN_U & -2 & -4 & -4 & 5 & 8 & 3 & 8 & 2 & 4 & 4 & 4 & 1 \\
\hline KAN_L & 0 & 0 & 1 & 0 & 0 & 1 & 0 & 0 & 1 & -1 & 0 & 1 \\
\hline TAS_U & 0 & 0 & -1 & 0 & 0 & 0 & 0 & 0 & 0 & 0 & 0 & 0 \\
\hline TAS_L & 0 & 0 & -1 & 0 & 0 & 0 & 0 & 0 & 0 & 0 & 0 & 0 \\
\hline NUK_U & X & X & 0 & $x$ & X & 0 & X & $x$ & -1 & X & $x$ & -4 \\
\hline NUK_L & 0 & 0 & 0 & 0 & 0 & 0 & 0 & 0 & 0 & 0 & 0 & 0 \\
\hline QAS_U & -2 & 0 & 0 & 0 & 0 & 0 & 0 & 0 & 0 & 0 & 0 & 0 \\
\hline QAS_L & 0 & 0 & 0 & 0 & 0 & 0 & 0 & 0 & 0 & 0 & 0 & 0 \\
\hline MEAN & -1 & -1 & -2 & 3 & 1 & 0 & 3 & -1 & -4 & 1 & -1 & -2 \\
\hline
\end{tabular}

Figure 8. (a) The summer (JJA) mean temperature from ERA-Interim compared to the three HCLIM38 experiments. Coloured dots indicate the anomalies between the lapse-rate-corrected model temperature and the observation at each PROMICE station. Numbers in the lower right corner indicate the root mean square error (top) and the average anomaly across the stations (bottom). (b) The monthly mean difference between the simulated lapse-rate-corrected temperature and the observations at each PROMICE station. The shading corresponds to the anomaly shading in (a), while the number indicates the anomaly in the number of melt days between the model and observations (ordered by latitude, north to south). Negative (positive) numbers indicate that the model has too few (too many) melt days compared to observations. Crosses on a white background indicate missing observational data. Model names have been shortened: ERA is ERA-Interim, ALR is ALARO24, ALD is ALADIN24 and A12 is ALADIN12.

the slopes of the ice sheet, which causes large variability between neighbouring grid cells, making the evaluation of model runs on scales like these difficult. Even with the lapse rate correction applied, some neighbouring upper and lower stations show very different biases, even of opposite sign. As is evident from Fig. 8b, despite the overall cold biases all three model versions achieve the correct number of days with melt at the three most southerly locations (both at the upper and lower stations). This indicates that even where the model monthly and seasonal mean temperatures are too low, they are still high enough to achieve the correct number of days with melt. Another consistent feature across the models is an underestimation of melt at the SCO stations (SCO_U and SCO_L) on the central east coast. The difference between 


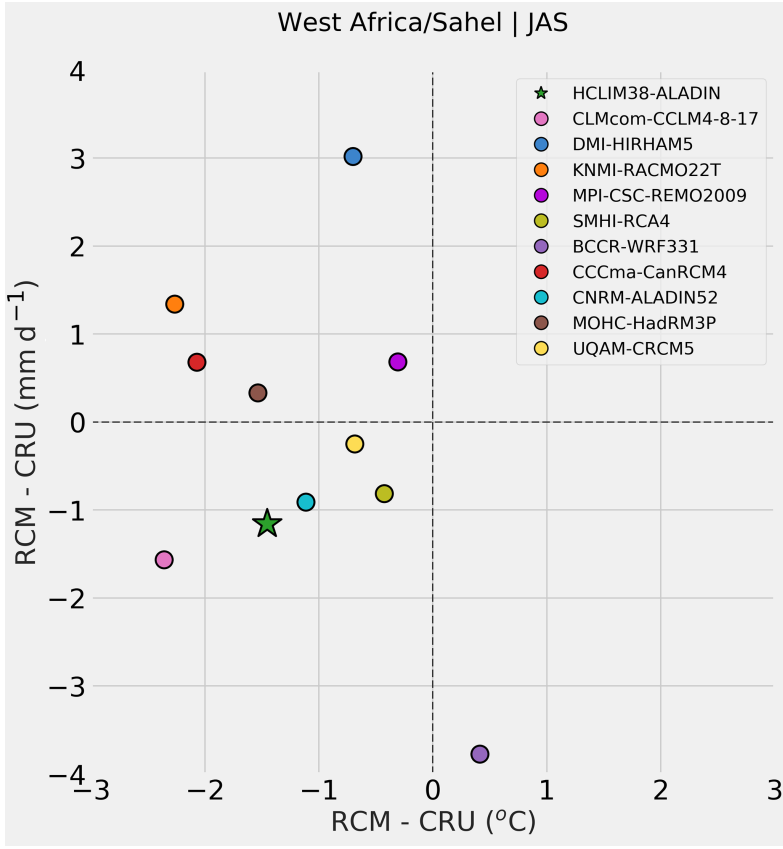

Figure 9. RCM biases (with respect to CRU) in mean JulySeptember (2000-2009) temperature and precipitation over West Africa $\left(7.5-15^{\circ} \mathrm{N}, 10^{\circ} \mathrm{W}-10^{\circ} \mathrm{E}\right)$. Circles represent individual RCMs from the CORDEX-Africa ensemble, and the star is HCLIM38-ALADIN. The horizontal resolution is $0.44^{\circ}$ or $50 \mathrm{~km}$.

the altitude in the model and the two stations is very large, indicating that the model (even at $12 \mathrm{~km}$ resolution) does not describe the complex terrain adequately. Looking at the temperature, a cold bias remains in August in all three experiments even after correcting for the elevation differences at the station location.

Similarly, the melting season in all three models exhibits a general pattern of positive biases, with too many days of melting in June and negative biases with too few days in August, i.e. a shift towards the earlier part of the summer. The northernmost sites (KPC and THU), in particular, appear to have a start of the melting season that is too early in the models.

The two $24 \mathrm{~km}$ experiments have a very similar spatial pattern of biases across the stations, the main difference being that ALARO24 is overall warmer than ALADIN24, resulting in increased warm biases and decreased cold biases. The warmer conditions in ALARO24 are also evident in north and north-eastern Greenland on the central more elevated parts of the ice sheet. Remarkably, the mean temperature in July even exceeds the melting point in a widespread area (not shown, but the pattern is reflected in the JJA mean temperature in Fig. 8a). This appears excessive compared to observations, wherein widespread melt on the interior ice sheet is rare (e.g. Nghiem et al., 2012). The most recent occurrence in July 2012 was related to exceptional conditions in the atmospheric circulation (Neff et al., 2014; Fausto et al.,
2016). While 2014 did have one of the highest melt extents observed, the central most elevated parts of the ice sheet did not experience melt (Tedesco et al., 2015). The spatial pattern of melt in ALADIN24 and ALADIN12 thus appears more consistent with the observed conditions in 2014. Considering the number of melt days at the PROMICE stations (Fig. 8b), the warmer conditions in ALARO24 result in slightly better agreement with observations in August (by increasing melt at the stations with a cold bias) but give too many melt days in total.

The increased resolution in ALADIN12 does not result in substantial changes overall compared to ALADIN24, despite the fact that the doubled resolution is able to resolve the steep slopes better. In terms of melt days, the average total number of melt days over the summer is closer to observations in ALADIN12.

Previous work by Mottram et al. (2017) reveals that HARMONIE-AROME (i.e. the NWP version of the convection-permitting model used in HCLIM) suffers from potential errors related to loss of the snow cover over glacier surfaces. When the snow cover is lost in their model setup, the exposed surface is not classified as ice and can unphysically heat up above the freezing point, distorting temperature and atmospheric circulation patterns compared to observations. None of the three experiments examined here show signs of complete loss of snow cover or the related issues reported earlier. Assessing whether this is a result of different model physics, coarser resolution or the updated surface scheme employed in our HCLIM38 simulations requires further investigation.

Together, these results indicate a reasonable performance of HCLIM38 in the Arctic melt season. While all three model setups tend to have the peak melting season occurring too early, the overall length of the melt season corresponds to the observed. As in previous studies, these results highlight the importance of very high resolutions for capturing the conditions on the coastal slopes of Greenland. The model-data comparison for the summer 2014 suggests a general cold bias over Greenland in HCLIM38, with ALARO physics resulting in slightly warmer conditions compared to ALADIN. While the warmer conditions in ALARO24 improve the average agreement with PROMICE observations in the ablation zone of the ice sheet, the additional warming on the northnortheastern part of the central ice sheet appears excessive compared to observations.

\subsection{Simulations over Africa}

In the Future Resilience for African CiTies And Lands project, FRACTAL (http://www.fractal.org.za, last access: 18 March 2020), HCLIM38 has been used for a study on the added value of dynamical downscaling over Africa. HCLIM38-ALADIN has been used for downscaling the ERA-Interim reanalysis over the CORDEX-Africa domain with four grid spacings: 25, 50, 100 and $200 \mathrm{~km}$. Addition- 
(a)

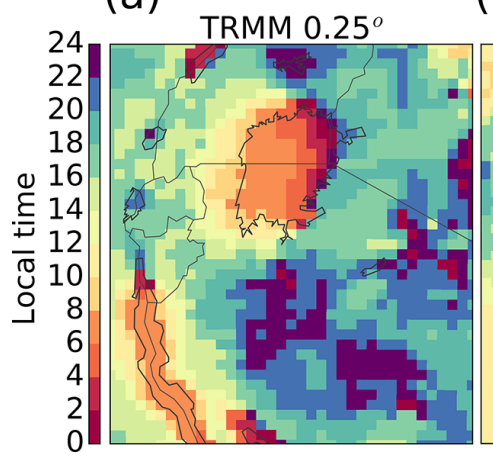

(b)

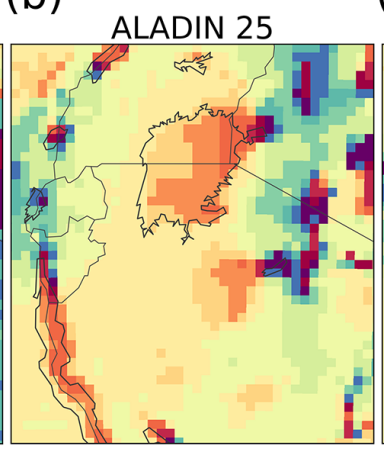

(c)

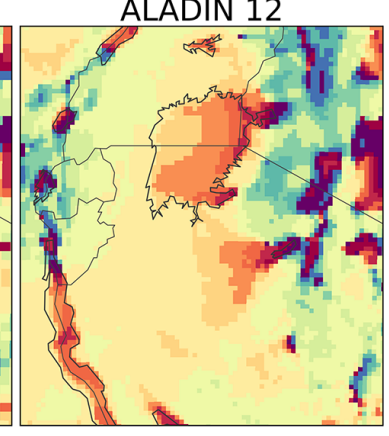

(d) AROME 2.5

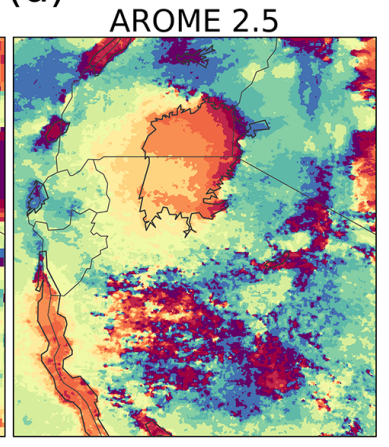

Figure 10. Time (local mean time) of maximum precipitation intensity during the diurnal cycle around Lake Victoria (2006) for (a) TRMM with $0.25^{\circ}$ resolution, (b) ALADIN with $25 \mathrm{~km}$ resolution, (c) ALADIN with $12 \mathrm{~km}$ resolution and (d) AROME with $2.5 \mathrm{~km}$ resolution. The time of maximum precipitation is based on a cubic spline fitted to the $3 \mathrm{~h}$ precipitation, and only days with more than $1 \mathrm{~mm} \mathrm{~d}^{-1}$ are included (see Nikulin et al., 2012, for details). The AROME simulation was forced by the ALADIN $12 \mathrm{~km}$ simulation shown in (c).

ally, within ELVIC CORDEX FPS, HCLIM38-AROME has been used to generate $2.5 \mathrm{~km}$ simulations over the Lake Victoria Basin using the ERA-Interim forcing and HCLIM38ALADIN as an intermediate model.

\subsubsection{HCLIM38-ALADIN performance over Africa}

Since HCLIM38 has not previously been applied over the African continent, the ALADIN pan-African simulation at $50 \mathrm{~km}$ was compared to the CORDEX-Africa (http://www. csag.uct.ac.za/cordex-africa, last access: 18 March 2020) RCM ensemble at about the same resolution (Nikulin et al., 2012, 2018). Figure 9 shows an example with the differences in mean July-September near-surface temperature and precipitation over the West Africa-Sahel region between the RCMs and the Climate Research Unit Time-Series (CRU, v. 4.01; Harris et al., 2014). HCLIM38-ALADIN is somewhat dry and cold, but the performance is well within the range of that of the CORDEX-Africa ensemble. On an annual timescale HCLIM38-ALADIN biases are mainly between -2 and $1.5^{\circ} \mathrm{C}$ for temperature and -1.5 and $1.5 \mathrm{~mm} \mathrm{~d}^{-1}$ for precipitation (Fig. S6), which is also within the range of the CORDEX-Africa ensemble.

\subsubsection{Convection-permitting simulations over Lake Victoria}

In order to define an optimal configuration for convectionpermitting HCLIM38-AROME simulations in Africa, a number of sensitivity experiments were performed for 20052006 over a wider Lake Victoria region within the ELVIC CORDEX FPS. The experiments include the downscaling of ERA-Interim by HCLIM38-ALADIN at $25 \mathrm{~km}$ (pan-Africa and eastern Africa) and $12 \mathrm{~km}$ (eastern Africa) resolution. In a subsequent step HCLIM38-AROME downscaled all three HCLIM38-ALADIN simulations over the Lake Victoria Basin at $2.5 \mathrm{~km}$. In the HCLIM38-ALADIN simulations precipitation over land is triggered early during the diurnal cycle compared to the Tropical Rainfall Measuring Mission (TRMM-3B42, v. 7; Huffman et al., 2007) (Fig. 10). This too early peak is a common problem in the majority of the CORDEX-Africa RCMs (Nikulin et al., 2012). In contrast to HCLIM38-ALADIN, the time of maximum precipitation intensity during the diurnal cycle over land is very well simulated by HCLIM38-AROME at $2.5 \mathrm{~km}$. This is in accordance with the HCLIM38-AROME results shown above for different European regions and with previous results using other CPRCMs (Finney et al., 2019), which strongly implies that the improvement is a result of the difference in model physics, i.e. the absence of convection parameterization, rather than only increased resolution.

\section{Conclusions and outlook}

HCLIM is a regional climate modelling system developed from NWP operational models. It is based on the collaboration between several European national meteorological institutes, with the main focus on the development of a CPRCM that can be used in the emerging field of convectionpermitting regional climate simulations. It is a relatively new modelling system for climate applications, with the currently recommended version HCLIM38 being used in an increasing number of national and international projects. The system is developed through a series of steps, starting from the ECMWF IFS, through the ALADIN-HIRLAM operational NWP model configurations, and finally to the specific climate modelling system. As such it contains a number of possible model configurations whose terminology needs proper explanation. Hence, this paper is both timely and needed for clarity and a proper understanding of the details of the system.

HCLIM38 consists of the three main model configurations: ALADIN, ALARO and HARMONIE-AROME, origi- 
nally intended to be used at different resolutions even though there is some overlap in the scales they can be applied for. They are all coupled to the same surface model, SURFEX, and use the same options for the surface. The current standard choice in HCLIM38 is ALADIN for grid spacing close to or larger than $10 \mathrm{~km}$ and HARMONIE-AROME for grid spacing less than $4 \mathrm{~km}$. HCLIM 38 has so far been used in a wide range of different climates, from equatorial to polar regions, and the initial analysis presented here indicates that it performs satisfactorily in those conditions. We also see that there are considerable benefits of using a CPRCM, particularly for sub-daily intense precipitation. HCLIM38-AROME is able to realistically simulate both the diurnal cycle and maximum intensity of sub-daily precipitation, which coarser RCMs or GCMs generally cannot accomplish because of the limitations of convection parameterizations (e.g. Brockhaus et al., 2008; Fosser et al., 2015; Prein et al., 2015). Our results contribute to this conceptual shift in climate simulations, which allows for better understanding and quantifying extremes in a changing climate. Further studies, which are underway or planned, will analyse and evaluate the modelling system for specific domains and applications.

One of the goals of HCLIM development is to interact closely with and benefit from NWP activities in model development, particularly related to HARMONIE-AROME. There are two main causes that currently hinder direct collaboration: HCLIM lags in cycles behind NWP, and HCLIM uses more sophisticated surface and soil model parameterizations. However, in the next operational cycle, cycle 43, both of these hurdles will be greatly diminished because the NWP surface setup is going to be the same as for climate applications, and both NWP and climate researchers are developing the same model cycle for the next operational version. This benefits both groups in a number of ways. The usually smaller climate groups can focus on climate-specific questions, while the general development is done in a wider context of NWP collaboration. At the same time, climate research provides insight into long-term model biases and feedbacks usually related to physical parameterizations, which can sometimes be masked in data-assimilation-driven NWP short-range forecasts.

One common topic for both NWP and climate model developments is the aerosol treatment. In a recent work by Rontu et al. (2019) the first steps towards an updated aerosol climatology based on the Copernicus Atmosphere Monitoring Service (CAMS; Copernicus 2019, Flemming et al., 2017) were taken. The authors introduced a simplified approach to include CAMS climatology in HARMONIE by lumping some species together and using this information to replace the existing aerosol climatology by Tegen et al. (1997). With the new CAMS approach the authors performed simulations in NWP and climate modes. The use of CAMS climatology led to slight improvements in the overall performance of HCLIM38 due to changes in the direct effect of aerosols. However, this simplified approach was just an initial step and the future developments will bring the full potential of the CAMS approach, including size and aerosol inherent optical properties for all available species. This approach also allows for the full usage of all aerosol species available from CAMS (without lumping), opens the possibility to use a unified source of aerosol information in radiation and cloud microphysics parameterizations, and enables the climate side to use significantly more temporally varying aerosol climatology.

Other ongoing and planned HARMONIE and HCLIM developments include coupling to a wave model, an ocean model and a river-routing model using the OASIS coupler available in SURFEX (Voldoire et al., 2017), a dynamic sea ice scheme and a new groundwater scheme.

Code availability. The ALADIN and HIRLAM consortia cooperate on the development of a shared system of model codes. The HCLIM model configuration forms part of this shared ALADINHIRLAM system. According to the ALADIN-HIRLAM collaboration agreement, all members of the ALADIN and HIRLAM consortia are allowed to license the shared ALADIN-HIRLAM codes within their home country for non-commercial research. Access to the HCLIM codes can be obtained by contacting one of the member institutes of the HIRLAM consortium (see links at: http://www.hirlam.org/index.php/hirlam-programme-53, last access: 18 March 2020; Lantsheer, 2016). The access will be subject to signing a standardized ALADINHIRLAM licence agreement (http://www.hirlam.org/index.php/ hirlam-programme-53/access-to-the-models, last access: 18 March 2020; HIRLAM, 2020). Some parts of the ALADIN-HIRLAM codes can be obtained by non-members through specific licences, such as in OpenIFS (https://confluence.ecmwf.int/display/OIFS, last access: 18 March 2020; Carver, 2018) and Open-SURFEX (https://www.umr-cnrm.fr/surfex, last access: 18 March 2020; SURFEX, 2020). The full code access is provided to the journal editor for peer review through a research licence.

Supplement. The supplement related to this article is available online at: https://doi.org/10.5194/gmd-13-1311-2020-supplement.

Author contributions. DB leads the HCLIM consortium and has initiated and collated the paper. Authors HdV, AD, OL, PL, DL, RAP, JCSP, ET, BvU and FW contributed to developing or running and evaluating the model, as well as writing the paper. Authors UA, YB, EK, GL, GN, JPP, ERC, PS, EvM and MW contributed either to the model development or to model evaluation and analysis of the results. All authors commented on the paper.

Competing interests. The authors declare that they have no conflict of interest. 
Acknowledgements. We thank Jeanette Onvlee-Hooimeijer and the anonymous reviewers for helpful suggestions about the paper. The ALADIN-HIRLAM system is developed and maintained by a large number of contributors at different institutions. We are grateful to all of them, and it is only through their continuous effort that the HCLIM development could have started. Computational and storage resources for the simulations have been provided by the European Centre for Medium-Range Weather Forecasts (ECMWF) and the computing resource Bi provided by the Swedish National Infrastructure for Computing (SNIC) at the Swedish National Supercomputing Centre (NSC) at Linköping University. Data from the Programme for Monitoring of the Greenland Ice Sheet (PROMICE) and the Greenland Analogue Project (GAP) were provided by the Geological Survey of Denmark and Greenland (GEUS) at http: //www.promice.dk (last access: 18 March 2020). The German station data were provided by the INTENSE project from the European Research Council (grant ERC-2013-CoG-617329). We acknowledge the EU-FP6 project UERRA for use of the E-OBS dataset (http://www.uerra.eu, last access: 18 March 2020; SURFEX, 2020), the Copernicus Climate Change Service and the data providers in the ECA\&D project (https://www.ecad.eu, last access: 18 March 2020).

Financial support. This research has been supported by Horizon 2020 (EUCP (grant no. 776613)) and the Maj and Tor Nessling foundation.

Review statement. This paper was edited by Julia Hargreaves and reviewed by two anonymous referees.

\section{References}

Alhammoud, B., Claud, C., Funatsu, B. M., Béranger, K., and Chaboureau, J.-P.: Patterns of Precipitation and Convection Occurrence over the Mediterranean Basin Derived from a Decade of Microwave Satellite Observations, Atmosphere, 5, 370-398, https://doi.org/10.3390/atmos5020370, 2014.

Ban, N., Schmidli, J., and Schär, C.: Evaluation of the convectionresolving regional climate modeling approach in decadelong simulations, J. Geophys. Res.-Atmos., 119, 7889-7907, https://doi.org/10.1002/2014JD021478, 2014.

Batrak, Y., Kourzeneva, E., and Homleid, M.: Implementation of a simple thermodynamic sea ice scheme, SICE version 1.0$38 \mathrm{~h} 1$, within the ALADIN-HIRLAM numerical weather prediction system version 38h1, Geosci. Model Dev., 11, 3347-3368, https://doi.org/10.5194/gmd-11-3347-2018, 2018.

Bauer, P., Beljaars, A., Ahlgrimm, M., Bechtold, P., Bidlot, J.-R., Bonavita, M., Bozzo, A., Forbes, R., Hólm, E. V., Leutbecher, M., Lopez, P., Magnusson, L., Prates, F., Rodwell, M., Sandu, I., Untch, A., and Vitart, F.: Model Cycle 38r2: Components and Performance, Tech. Rep. 704, ECMWF, https://doi.org/10.21957/xc1r0lj61, 2013.

Bazile, E., Marquet, P., Bouteloup, Y., and Bouyssel, F.: The Turbulent Kinetic Energy (TKE) scheme in the NWP models at Meteo France, in: Workshop on Workshop on Diurnal cycles and the stable boundary layer, 7-10 November 2011, 127-135, ECMWF,
Shinfield Park, Reading, available at: https://www.ecmwf.int/ node/8006 (last access: 18 March 2020), 2012.

Bechtold, P., Cuijpers, J. W. M., Mascart, P., and Trouilhet, P.: Modeling of Trade Wind Cumuli with a LowOrder Turbulence Model: Toward a Unified Description of $\mathrm{Cu}$ and Se Clouds in Meteorological Models, J. Atmos. Sci., 52, 455-463, https://doi.org/10.1175/15200469(1995)052<0455:MOTWCW>2.0.CO;2, 1995.

Bechtold, P., Bazile, E., Guichard, F., Mascart, P., and Richard, E.: A mass-flux convection scheme for regional and global models, Q. J. Roy. Meteorol. Soc., 127, 869-886, 2001.

Belamari, S.: Report on uncertainty estimates of an optimal bulk formulation for surface turbulent fluxes, Marine EnviRonment and Security for the European Area - Integrated Project (MERSEA IP), Tech. Rep. Deliverable D4.1.2, 2005.

Belamari, S. and Pirani, A.: Validation of the optimal heat and momentum fluxes using the ORCA2-LIM global ocean-ice model, Marine EnviRonment and Security for the European Area - Integrated Project (MERSEA IP), Tech. Rep. Deliverable D4.1.3, 2007.

Bénard, P., Vivoda, J., Mašek, J., Smolíková, P., Yessad, K., Smith, C., Brožková, R., and Geleyn, J.-F.: Dynamical kernel of the Aladin-NH spectral limited-area model: Revised formulation and sensitivity experiments, Q. J. Roy. Meteorol. Soc., 136, 155-169, https://doi.org/10.1002/qj.522, 2010.

Bengtsson, L., Andrae, U., Aspelien, T., Batrak, Y., Calvo, J., de Rooy, W., Gleeson, E., Hansen-Sass, B., Homleid, M., Hortal, M., Ivarsson, K.-I., Lenderink, G., Niemelä, S., Nielsen, K. P., Onvlee, J., Rontu, L., Samuelsson, P., Muñoz, D. S., Subias, A., Tijm, S., Toll, V., Yang, X., and Køltzow, M. Ø.: The HARMONIE-AROME Model Configuration in the ALADINHIRLAM NWP System, Mon. Weather Rev., 145, 1919-1935, https://doi.org/10.1175/MWR-D-16-0417.1, 2017.

Berthou, S., Kendon, E. J., Chan, S. C., Ban, N., Leutwyler, D., Schär, C., and Fosser, G.: Pan-European climate at convectionpermitting scale: a model intercomparison study, Clim. Dynam., https://doi.org/10.1007/s00382-018-4114-6, in press, 2018.

Boone, A.: Modelisation des processus hydrologiques dans le schema de surface ISBA: Inclusion d'un reservoir hydrologique, du gel et modelisation de la neige, Ph.D. dissertation, University Paul Sabatier, Toulouse, France, 2000 (in French).

Boone, A. and Etchevers, P.: An Intercomparison of Three Snow Schemes of Varying Complexity Coupled to the Same Land Surface Model: Local-Scale Evaluation at an Alpine Site, J. Hydrometeorol., 2, 374-394, https://doi.org/10.1175/15257541(2001)002<0374:AIOTSS>2.0.CO;2, 2001.

Boone, A., Calvet, J.-C., and Noilhan, J.: Inclusion of a third soil layer in a land surface scheme using the force-restore method, J. Appl. Meteor, 38, 1611-1630, https://doi.org/10.1175/15200450(1999)038,1611:IOATSL.2.0.CO;2, 1999.

Bougeault, P.: A Simple Parameterization of the LargeScale Effects of Cumulus Convection, Mon. Weather Rev., 113, 2108-2121, https://doi.org/10.1175/15200493(1985)113<2108:ASPOTL>2.0.CO;2, 1985.

Bougeault, P. and Lacarrere, P.: Parameterization of OrographyInduced Turbulence in a Mesobeta-Scale Model, Mon. Weather Rev., 117, 1872-1890, https://doi.org/10.1175/15200493(1989)117<1872:POOITI>2.0.CO;2, 1989. 
Bouteloup, Y., Bouyssel, F., and Marquet, P.: Improvements of Lopez's progonostic large scale cloud and precipitation scheme, ALADIN Newsletter, 28, 66-73, 2005.

Brockhaus, P., Lüthi, D., and Schär, C.: Aspects of the diurnal cycle in a regional climate model, Meteorologische Z., 17, 433-443, https://doi.org/10.1127/0941-2948/2008/0316, 2008.

Brown, J., Jakob, C., and Haynes, J.: An Evaluation of Rainfall Frequency and Intensity over the Australian Region in a Global Climate Model, J. Climate, 23, 6504-6525, https://doi.org/10.1175/2010JCLI3571.1, 2010.

Carver, G.: About OpenIFS, available at: https://confluence.ecmwf. int/display/OIFS (last access: 18 March 2020), 2018.

Catry, B., Geleyn, J.-F., Bouyssel, F., Cedilnik, J., Brožková, R., Derková, M., and Mladek, R.: A new sub-grid scale lift formulation in a mountain drag parameterisation scheme, Meteorologische Z., 17, 193-208, https://doi.org/10.1127/09412948/2008/0272, 2008.

Christensen, J. H. and Christensen, O. B.: A summary of the PRUDENCE model projections of changes in European climate by the end of this century, Clim. Change, 81, 7-30, https://doi.org/10.1007/s10584-006-9210-7, 2007.

Colin, J., Déqué, M., Radu, R., and Somot, S.: Sensitivity study of heavy precipitation in Limited Area Model climate simulations: influence of the size of the domain and the use of the spectral nudging technique, Tellus A: Dynam. Meteorol. Oceanogr., 62, 591-604, https://doi.org/10.1111/j.1600-0870.2010.00467.x, 2010.

Coppola, E., Sobolowski, S., Pichelli, E., Raffaele, F., Ahrens, B., Anders, I., Ban, N., Bastin, S., Belda, M., Belušić, D., CaldasAlvarez, A., Cardoso, R. M., Davolio, S., Dobler, A., Fernandez, J., Fita, L., Fumiere, Q., Giorgi, F., Goergen, K., Güttler, I., Halenka, T., Heinzeller, D., Hodnebrog, Ø., Jacob, D., Kartsios, S., Katragkou, E., Kendon, E., Khodayar, S., Kunstmann, H., Knist, S., Lavín-Gullón, A., Lind, P., Lorenz, T., Maraun, D., Marelle, L., van Meijgaard, E., Milovac, J., Myhre, G., Panitz, H.-J., Piazza, M., Raffa, M., Raub, T., Rockel, B., Schär, C., Sieck, K., Soares, P. M. M., Somot, S., Srnec, L., Stocchi, P., Tölle, M. H., Truhetz, H., Vautard, R., de Vries, H., and Warrach-Sagi, K.: A first-of-its-kind multi-model convection permitting ensemble for investigating convective phenomena over Europe and the Mediterranean, Clim. Dynam., https://doi.org/10.1007/s00382-018-4521-8, in press, 2018.

Courtier, P., Freydier, C., Geleyn, J.-F., Rabier, F., and Rochas, M.: The ARPEGE project at Météo-France, in: Proceedings of 1991 ECMWF Seminar on Numerical Methods in Atmospheric Models, 193-231, ECMWF, Reading, United Kingdom, 1991.

Crespi, A., Lussana, C., Brunetti, M., Dobler, A., Maugeri, M., and Tveito, O. E.: High-resolution monthly precipitation climatologies over Norway (1981-2010): Joining numerical model data sets and in situ observations, Int. J. Climatol., 39, 2057-2070, https://doi.org/10.1002/joc.5933, 2019.

Cuxart, J., Bougeault, P., and Redelsperger, J.-L.: A turbulence scheme allowing for mesoscale and large-eddy simulations, Q. J. Roy. Meteorol. Soc., 126, 1-30, https://doi.org/10.1002/qj.49712656202, 2000.

Daniel, M., Lemonsu, A., Déqué, M., Somot, S., Alias, A., and Masson, V.: Benefits of explicit urban parameterization in regional climate modeling to study climate and city interactions,
Clim. Dynam., 52, 2745-2764, https://doi.org/10.1007/s00382018-4289-x, 2019.

Darmaraki, S., Somot, S., Sevault, F., and Nabat, P.: Past Variability of Mediterranean Sea Marine Heatwaves, Geophys. Res. Lett., 46, 9813-9823, https://doi.org/10.1029/2019GL082933, 2019.

Decharme, B. and Douville, H.: Introduction of a sub-grid hydrology in the ISBA land surface model, Clim. Dynam., 26, 65-78, https://doi.org/10.1007/s00382-005-0059-7, 2006.

Decharme, B., Boone, A., Delire, C., and Noilhan, J.: Local evaluation of the Interaction between Soil Biosphere Atmosphere soil multilayer diffusion scheme using four pedotransfer functions, J. Geophys. Res.-Atmos., 116, D20126, https://doi.org/10.1029/2011JD016002, 2011.

Decharme, B., Brun, E., Boone, A., Delire, C., Le Moigne, P., and Morin, S.: Impacts of snow and organic soils parameterization on northern Eurasian soil temperature profiles simulated by the ISBA land surface model, The Cryosphere, 10, 853-877, https://doi.org/10.5194/tc-10-853-2016, 2016.

Decharme, B., Delire, C., Minvielle, M., Colin, J., Vergnes, J.-P., Alias, A., Saint-Martin, D., Séférian, R., Sénési, S., and Voldoire, A.: Recent changes in the ISBA-CTRIP land surface system for using in the CNRM-CM6 climate model and in global off-line hydrological applications, J. Adv. Model. Earth Syst., 11, 12071252, https://doi.org/10.1029/2018MS001545, 2019.

Dee, D. P., Uppala, S. M., Simmons, A. J., Berrisford, P., Poli, P., Kobayashi, S., Andrae, U., Balmaseda, M. A., Balsamo, G., Bauer, P., Bechtold, P., Beljaars, A. C. M., van de Berg, L., Bidlot, J., Bormann, N., Delsol, C., Dragani, R., Fuentes, M., Geer, A. J., Haimberger, L., Healy, S. B., Hersbach, H., Hólm, E. V., Isaksen, L., Kållberg, P., Köhler, M., Matricardi, M., McNally, A. P., Monge-Sanz, B. M., Morcrette, J.-J., Park, B.-K., Peubey, C., de Rosnay, P., Tavolato, C., Thépaut, J.-N., and Vitart, F.: The ERA-Interim reanalysis: configuration and performance of the data assimilation system, Q. J. Roy. Meteorol. Soc., 137, 553597, https://doi.org/10.1002/qj.828, 2011.

de Rooy, W. C. and Siebesma, A. P.: A Simple Parameterization for Detrainment in Shallow Cumulus, Mon. Weather Rev., 136, 560-576, https://doi.org/10.1175/2007MWR2201.1, 2008.

Douville, H., Royer, J. F., and Mahfouf, J. F.: A new snow parameterization for the Météo-France climate model, Clim. Dynam., 12, 21-35, https://doi.org/10.1007/BF00208760, 1995.

Drugé, T., Nabat, P., Mallet, M., and Somot, S.: Model simulation of ammonium and nitrate aerosols distribution in the Euro-Mediterranean region and their radiative and climatic effects over 1979-2016, Atmos. Chem. Phys., 19, 3707-3731, https://doi.org/10.5194/acp-19-3707-2019, 2019.

Déqué, M., Dreveton, C., Braun, A., and Cariolle, D.: The ARPEGE/IFS atmosphere model: a contribution to the French community climate modelling, Clim. Dynam., 10, 249-266, https://doi.org/10.1007/BF00208992, 1994.

Dümenil, L. and Todini, E.: Chapter 9 - A rainfall-runoff scheme for use in the Hamburg climate model, in: Advances in Theoretical Hydrology, edited by: O'Kane, J. P., European Geophysical Society Series on Hydrological Sciences, 129-157, Elsevier, Amsterdam, https://doi.org/10.1016/B978-0-444-898319.50016-8, 1992.

Ďurán, I. B., Geleyn, J.-F., and Váňa, F.: A Compact Model for the Stability Dependency of TKE ProductionDestruction-Conversion Terms Valid for the Whole Range 
of Richardson Numbers, J. Atmos. Sci., 71, 3004-3026, https://doi.org/10.1175/JAS-D-13-0203.1, 2014.

Erokhina, O., Rogozhina, I., Prange, M., Bakker, P., Bernales, J., Paul, A., and Schulz, M.: Dependence of slope lapse rate over the Greenland ice sheet on background climate, J. Glaciol., 63, 568-572, 2017.

Ettema, J., van den Broeke, M. R., van Meijgaard, E., and van de Berg, W. J.: Climate of the Greenland ice sheet using a high-resolution climate model - Part 2: Near-surface climate and energy balance, The Cryosphere, 4, 529-544, https://doi.org/10.5194/tc-4-529-2010, 2010.

FAO: World reference base for soil resources 2006, A framework for international classification, correlation and communication, Tech. Rep. No. 103, Food and Agriculture Organization of the United Nations, Rome, Italy, iSSN 0532-0488, 2006.

Faroux, S., Kaptué Tchuenté, A. T., Roujean, J.-L., Masson, V., Martin, E., and Le Moigne, P.: ECOCLIMAP-II/Europe: a twofold database of ecosystems and surface parameters at $1 \mathrm{~km}$ resolution based on satellite information for use in land surface, meteorological and climate models, Geosci. Model Dev., 6, 563582, https://doi.org/10.5194/gmd-6-563-2013, 2013.

Fausto, R. S. and van As, D.: Programme for monitoring of the Greenland ice sheet (PROMICE): Automatic weather station data. Version: v03, Dataset published via Geological Survey of Denmark and Greenland, https://doi.org/10.22008/promice/data/aws, 2019.

Fausto, R. S., van As, D., Box, J. E., Colgan, W., Langen, P. L., and Mottram, R. H.: The implication of nonradiative energy fluxes dominating Greenland ice sheet exceptional ablation area surface melt in 2012, Geophys. Res. Lett., 43, 2649-2658, https://doi.org/10.1002/2016GL067720, 2016.

Finney, D. L., Marsham, J. H., Jackson, L. S., Kendon, E. J., Rowell, D. P., Boorman, P. M., Keane, R. J., Stratton, R. A., and Senior, C. A.: Implications of Improved Representation of Convection for the East Africa Water Budget Using a Convection-Permitting Model, J. Climate, 32, 2109-2129, https://doi.org/10.1175/JCLID-18-0387.1, 2019.

Flemming, J., Benedetti, A., Inness, A., Engelen, R. J., Jones, L., Huijnen, V., Remy, S., Parrington, M., Suttie, M., Bozzo, A., Peuch, V.-H., Akritidis, D., and Katragkou, E.: The CAMS interim Reanalysis of Carbon Monoxide, Ozone and Aerosol for 2003-2015, Atmos. Chem. Phys., 17, 1945-1983, https://doi.org/10.5194/acp-17-1945-2017, 2017.

Fosser, G., Khodayar, S., and Berg, P.: Benefit of convection permitting climate model simulations in the representation of convective precipitation, Clim. Dynam., 44, 45-60, https://doi.org/10.1007/s00382-014-2242-1, 2015.

Fouquart, Y. and Bonnel, B.: Computations of solar heating of the earth's atmosphere: A new parameterization, Beitrage zur Physik der Atmosphare, 53, 35-62, 1980.

Frogner, I.-L., Andrae, U., Bojarova, J., Callado, A., Escribà, P., Feddersen, H., Hally, A., Kauhanen, J., Randriamampianina, R., Singleton, A., Smet, G., van der Veen, S., and Vignes, O.: HarmonEPS - the HARMONIE ensemble prediction system, Weather Forecast., 34, 1909-1937, https://doi.org/10.1175/WAF-D-19-0030.1, 2019.

Fumière, Q., Déqué, M., Nuissier, O., Somot, S., Alias, A., Caillaud, C., Laurantin, O., and Seity, Y.: Extreme rainfall in Mediterranean France during the fall: added value of the CNRM-
AROME Convection-Permitting Regional Climate Model, Clim. Dynam., https://doi.org/10.1007/s00382-019-04898-8, in press, 2019.

Geleyn, J.: Use of a Modified Richardson Number for Parameterizing the Effect of Shallow Convection, J. Meteorol. Soc. JPN II, 64A, 141-149, https://doi.org/10.2151/jmsj1965.64A.0_141, 1987.

Geleyn, J.-F., Váňa, F., Cedilnik, J., Tudor, M., and Catry, B.: An intermediate solution between diagnostic exchange coefficients and prognostic TKE methods for vertical turbulent transport, in: CAS/JSC WGNE "Blue Book" annual report: Research Activities in Atmospheric and Ocean Modelling, edited by: Côté, J., 4.11-4.12, 2006.

Geleyn, J.-F., Mašek, J., Brožková, R., Kuma, P., Degrauwe, D., Hello, G., and Pristov, N.: Single interval longwave radiation scheme based on the net exchanged rate decomposition with bracketing, Q. J. Roy. Meteorol. Soc., 143, 1313-1335, https://doi.org/10.1002/qj.3006, 2017.

Gerard, L., Piriou, J.-M., Brožková, R., Geleyn, J.-F., and Banciu, D.: Cloud and Precipitation Parameterization in a Meso-Gamma-Scale Operational Weather Prediction Model, Mon. Weather Rev., 137, 3960-3977, https://doi.org/10.1175/2009MWR2750.1, 2009.

Giorgi, F.: Climate change hot-spots, Geophys. Res. Lett., 33, L08707, https://doi.org/10.1029/2006GL025734, 2006.

Guérémy, J. F.: A continuous buoyancy based convection scheme: one-and three-dimensional validation, Tellus A: Dynam. Meteorol. Oceanogr., 63, 687-706, https://doi.org/10.1111/j.16000870.2011.00521.x, 2011.

Harris, I., Jones, P., Osborn, T., and Lister, D.: Updated high-resolution grids of monthly climatic observations the CRU TS3.10 Dataset, Int. J. Climatol., 34, 623-642, https://doi.org/10.1002/joc.3711, 2014.

Haylock, M. R., Hofstra, N., Klein Tank, A. M. G., Klok, E. J., Jones, P. D., and New, M.: A European daily highresolution gridded data set of surface temperature and precipitation for 1950-2006, J. Geophys. Res.-Atmos., 113, D20119, https://doi.org/10.1029/2008JD010201, 2008.

HIRLAM: Access to the models, available at: http://www.hirlam. org/index.php/hirlam-programme-53/access-to-the-models, last access: 18 March 2020.

Huffman, G. J., Bolvin, D. T., Nelkin, E. J., Wolff, D. B., Adler, R. F., Gu, G., Hong, Y., Bowman, K. P., and Stocker, E. F.: The TRMM Multisatellite Precipitation Analysis (TMPA): Quasi-Global, Multiyear, Combined-Sensor Precipitation Estimates at Fine Scales, J. Hydrometeorol., 8, 38-55, https://doi.org/10.1175/JHM560.1, 2007.

Iacono, M. J., Delamere, J. S., Mlawer, E. J., Shephard, M. W., Clough, S. A., and Collins, W. D.: Radiative forcing by longlived greenhouse gases: Calculations with the AER radiative transfer models, J. Geophys. Res.-Atmos., 113, D13103, https://doi.org/10.1029/2008JD009944, 2008.

Jacob, D., Petersen, J., Eggert, B., Alias, A., Christensen, O. B., Bouwer, L. M., Braun, A., Colette, A., Déqué, M., Georgievski, G., Georgopoulou, E., Gobiet, A., Menut, L., Nikulin, G., Haensler, A., Hempelmann, N., Jones, C., Keuler, K., Kovats, S., Kröner, N., Kotlarski, S., Kriegsmann, A., Martin, E., van Meijgaard, E., Moseley, C., Pfeifer, S., Preuschmann, S., Radermacher, C., Radtke, K., Rechid, D., Rounsevell, M., 
Samuelsson, P., Somot, S., Soussana, J.-F., Teichmann, C., Valentini, R., Vautard, R., Weber, B., and Yiou, P.: EUROCORDEX: new high-resolution climate change projections for European impact research, Reg. Environ. Change, 14, 563-578, https://doi.org/10.1007/s10113-013-0499-2, 2014.

Kendon, E. J., Ban, N., Roberts, N. M., Fowler, H. J., Roberts, M. J., Chan, S. C., Evans, J. P., Fosser, G., and Wilkinson, J. M.: Do convection-permitting regional climate models improve projections of future precipitation change?, B. Am. Meteorol. Soc., 98, 79-93, 2017.

Khodayar, S., Raff, F., Kalthoff, N., and Bock, O.: Diagnostic study of a high-precipitation event in the Western Mediterranean: adequacy of current operational networks, Q. J. Roy. Meteorol. Soc., 142, 72-85, https://doi.org/10.1002/qj.2600, 2016.

Klein Tank, A. M. G., Wijngaard, J. B., Können, G. P., Böhm, R., Demarée, G., Gocheva, A., Mileta, M., Pashiardis, S., Hejkrlik, L., Kern-Hansen, C., Heino, R., Bessemoulin, P., MüllerWestermeier, G., Tzanakou, M., Szalai, S., Pálsdóttir, T., Fitzgerald, D., Rubin, S., Capaldo, M., Maugeri, M., Leitass, A., Bukantis, A., Aberfeld, R., van Engelen, A. F. V., Forland, E., Mietus, M., Coelho, F., Mares, C., Razuvaev, V., Nieplova, E., Cegnar, T., Antonio López, J., Dahlström, B., Moberg, A., Kirchhofer, W., Ceylan, A., Pachaliuk, O., Alexander, L. V., and Petrovic, P.: Daily dataset of 20th-century surface air temperature and precipitation series for the European Climate Assessment, Int. J. Climatol., 22, 1441-1453, https://doi.org/10.1002/joc.773, 2002.

Kotlarski, S., Keuler, K., Christensen, O. B., Colette, A., Déqué, M., Gobiet, A., Goergen, K., Jacob, D., Lüthi, D., van Meijgaard, E., Nikulin, G., Schär, C., Teichmann, C., Vautard, R., Warrach-Sagi, K., and Wulfmeyer, V.: Regional climate modeling on European scales: a joint standard evaluation of the EUROCORDEX RCM ensemble, Geosci. Model Dev., 7, 1297-1333, https://doi.org/10.5194/gmd-7-1297-2014, 2014.

Kourzeneva, E., Asensio, H., Martin, E., and Faroux, S.: Global gridded dataset of lake coverage and lake depth for use in numerical weather prediction and climate modelling, Tellus A: Dynam. Meteorol. Oceanogr., 64, 15640, https://doi.org/10.3402/tellusa.v64i0.15640, 2012.

Lantsheer, F.: About the HiRLAM programme, available at: http: //www.hirlam.org/index.php/hirlam-programme-53 (last access: 18 March 2020), 2016.

Lascaux, F., Richard, E., and Pinty, J.-P.: Numerical simulations of three different MAP IOPs and the associated microphysical processes, Q. J. Roy. Meteorol. Soc., 132, 1907-1926, https://doi.org/10.1256/qj.05.197, 2006.

Lenderink, G. and Holtslag, A. A. M.: An updated lengthscale formulation for turbulent mixing in clear and cloudy boundary layers, Q. J. Roy. Meteorol. Soc., 130, 3405-3427, https://doi.org/10.1256/qj.03.117, 2004.

Lenderink, G., Belušić, D., Fowler, H. J., Kjellström, E., Lind, P., van Meijgaard, E., van Ulft, B., and de Vries, H.: Systematic increases in the thermodynamic response of hourly precipitation extremes in an idealized warming experiment with a convection-permitting climate model, Environ. Res. Lett., 14, 074012, https://doi.org/10.1088/1748-9326/ab214a, 2019.

Lind, P., Lindstedt, D., Kjellström, E., and Jones, C.: Spatial and Temporal Characteristics of Summer Precipitation over Central Europe in a Suite of High-Resolution Climate Models,
J. Climate, 29, 3501-3518, https://doi.org/10.1175/JCLI-D-150463.1, 2016.

Lindstedt, D., Lind, P., Kjellström, E., and Jones, C.: A new regional climate model operating at the meso-gamma scale: performance over Europe, Tellus A: Dynam. Meteorol. Oceanogr., 67, 24138, https://doi.org/10.3402/tellusa.v67.24138, 2015.

Lionello, P., Malanotte-Rizzoli, P., Boscolo, R., Alpert, P., Artale, V., Li, L., Luterbacher, J., May, W., Trigo, R. M., Tsimplis, M., Ulbrich, U., and Xoplaki, E.: The Mediterranean climate: an overview of the main characteristics and issues, in: Mediterranean Climate Variability, edited by: Lionello, P., MalanotteRizzoli, P., and Boscolo, R., 1-26, Elsevier, 2006.

Lopez, P.: Implementation and validation of a new prognostic large-scale cloud and precipitation scheme for climate and dataassimilation purposes, Q. J. Roy. Meteorol. Soc., 128, 229-257, https://doi.org/10.1256/00359000260498879, 2002.

Lucas-Picher, P., Wulff-Nielsen, M., Christensen, J. H., Aðalgeirsdóttir, G., Mottram, R., and Simonsen, S. B.: Very high resolution regional climate model simulations over Greenland: Identifying added value, J. Geophys. Res.-Atmos., 117, D02108, https://doi.org/10.1029/2011JD016267, 2012.

Lussana, C., Saloranta, T., Skaugen, T., Magnusson, J., Tveito, O. E., and Andersen, J.: seNorge 2 daily precipitation, an observational gridded dataset over Norway from 1957 to the present day, Earth Syst. Sci. Data, 10, 235-249, https://doi.org/10.5194/essd10-235-2018, 2018a.

Lussana, C., Tveito, O. E., and Uboldi, F.: Three-dimensional spatial interpolation of $2 \mathrm{~m}$ temperature over Norway, Q. J. Roy. Meteorol. Soc., 144, 344-364, https://doi.org/10.1002/qj.3208, 2018b.

Lussana, C., Tveito, O. E., Dobler, A., and Tunheim, K.: seNorge_2018, daily precipitation, and temperature datasets over Norway, Earth Syst. Sci. Data, 11, 1531-1551, https://doi.org/10.5194/essd-11-1531-2019, 2019.

Malardel, S. and Ricard, D.: An alternative cell-averaged departure point reconstruction for pointwise semi-Lagrangian transport schemes, Q. J. Roy. Meteorol. Soc., 141, 2114-2126, https://doi.org/10.1002/qj.2509, 2015.

Matte, D., Laprise, R., Thériault, J. M., and Lucas-Picher, P.: Spatial spin-up of fine scales in a regional climate model simulation driven by low-resolution boundary conditions, Clim. Dynam., 49, 563-574, https://doi.org/10.1007/s00382-016-3358-2, 2017.

Mascart, P. J. and Bougeault, P.: The Meso-NH atmospheric simulation system: Scientific documentation. Part III: Physics, Tech. rep., Méteo-France, available at: http://mesonh.aero.obs-mip.fr/ mesonh/dir_doc/book1_m48_19jan2009/scidoc_p3.pdf (last access: 18 March 2020), 2011.

Mašek, J., Geleyn, J.-F., Brožková, R., Giot, O., Achom, H. O., and Kuma, P.: Single interval shortwave radiation scheme with parameterized optical saturation and spectral overlaps, Q. J. Roy. Meteorol. Soc., 142, 304-326, https://doi.org/10.1002/qj.2653, 2016.

Masson, V.: A Physically-Based Scheme For The Urban Energy Budget In Atmospheric Models, Bound.-Lay. Meteorol., 94, 357-397, https://doi.org/10.1023/A:1002463829265, 2000.

Masson, V., Le Moigne, P., Martin, E., Faroux, S., Alias, A., Alkama, R., Belamari, S., Barbu, A., Boone, A., Bouyssel, F., Brousseau, P., Brun, E., Calvet, J.-C., Carrer, D., Decharme, B., Delire, C., Donier, S., Essaouini, K., Gibelin, A.-L., Giordani, H., 
Habets, F., Jidane, M., Kerdraon, G., Kourzeneva, E., Lafaysse, M., Lafont, S., Lebeaupin Brossier, C., Lemonsu, A., Mahfouf, J.-F., Marguinaud, P., Mokhtari, M., Morin, S., Pigeon, G., Salgado, R., Seity, Y., Taillefer, F., Tanguy, G., Tulet, P., Vincendon, B., Vionnet, V., and Voldoire, A.: The SURFEXv7.2 land and ocean surface platform for coupled or offline simulation of earth surface variables and fluxes, Geosci. Model Dev., 6, 929-960, https://doi.org/10.5194/gmd-6-929-2013, 2013.

Mironov, D., Heise, E., Kourzeneva, E., Ritter, B., Schneider, N., and Terzhevik, A.: Implementation of the lake parameterisation scheme FLake into the numerical weather prediction model COSMO, Boreal Environ. Res., 15, 218-230, 2010.

Mlawer, E. J., Taubman, S. J., Brown, P. D., Iacono, M. J., and Clough, S. A.: Radiative transfer for inhomogeneous atmospheres: RRTM, a validated correlated-k model for the longwave, J. Geophys. Res.-Atmos., 102, 16663-16682, https://doi.org/10.1029/97JD00237, 1997.

Mottram, R., Nielsen, K. P., Gleeson, E., and Yang, X.: Modelling Glaciers in the HARMONIE-AROME NWP model, Adv. Sci. Res., 14, 323-334, https://doi.org/10.5194/asr-14-323-2017, 2017.

Müller, M., Homleid, M., Ivarsson, K.-I., Køltzow, M. A. Ø., Lindskog, M., Midtbø, K. H., Andrae, U., Aspelien, T., Berggren, L., Bjørge, D., Dahlgren, P., Kristiansen, J., Randriamampianina, R., Ridal, M., and Vignes, O.: AROME-MetCoOp: A Nordic Convective-Scale Operational Weather Prediction Model, Weather Forecast., 32, 609-627, https://doi.org/10.1175/WAFD-16-0099.1, 2017.

Neff, W., Compo, G. P., Martin Ralph, F., and Shupe, M. D.: Continental heat anomalies and the extreme melting of the Greenland ice surface in 2012 and 1889: Melting of Greenland in 1889 and 2012, J. Geophy. Res.-Atmos., 119, 6520-6536, https://doi.org/10.1002/2014JD021470, 2014.

Nghiem, S. V., Hall, D. K., Mote, T. L., Tedesco, M., Albert, M. R., Keegan, K., Shuman, C. A., DiGirolamo, N. E., and Neumann, G.: The extreme melt across the Greenland ice sheet in 2012, Geophys. Res. Lett., 39, L20502, https://doi.org/10.1029/2012GL053611, 2012.

Nikulin, G., Jones, C., Giorgi, F., Asrar, G., Büchner, M., CerezoMota, R., Christensen, O. B., Déqué, M., Fernandez, J., Hänsler, A., van Meijgaard, E., Samuelsson, P., Sylla, M. B., and Sushama, L.: Precipitation Climatology in an Ensemble of CORDEX-Africa Regional Climate Simulations, J. Climate, 25, 6057-6078, https://doi.org/10.1175/JCLI-D-11-00375.1, 2012.

Nikulin, G., Lennard, C., Dosio, A., Kjellström, E., Chen, Y., Hänsler, A., Kupiainen, M., Laprise, R., Mariotti, L., Maule, C. F., Meijgaard, E. v., Panitz, H.-J., Scinocca, J. F., and Somot, S.: The effects of 1.5 and 2 degrees of global warming on Africa in the CORDEX ensemble, Environ. Res. Lett., 13, 065003, https://doi.org/10.1088/1748-9326/aab1b1, 2018.

Noël, B., van de Berg, W. J., van Wessem, J. M., van Meijgaard, E., van As, D., Lenaerts, J. T. M., Lhermitte, S., Kuipers Munneke, P., Smeets, C. J. P. P., van Ulft, L. H., van de Wal, R. S. W., and van den Broeke, M. R.: Modelling the climate and surface mass balance of polar ice sheets using RACMO2 Part 1: Greenland (1958-2016), The Cryosphere, 12, 811-831, https://doi.org/10.5194/tc-12-811-2018, 2018.

Noilhan, J. and Planton, S.: A Simple Parameterization of Land Surface Processes for Meteorological Models, Mon.
Weather Rev., 117, 536-549, https://doi.org/10.1175/15200493(1989)117<0536:ASPOLS>2.0.CO;2, 1989.

Overeem, A., Holleman, I., and Buishand, A.: Derivation of a 10-Year Radar-Based Climatology of Rainfall, J. Appl. Meteorol. Climatol., 48, 1448-1463, https://doi.org/10.1175/2009JAMC1954.1, 2009.

Pergaud, J., Masson, V., Malardel, S., and Couvreux, F.: A Parameterization of Dry Thermals and Shallow Cumuli for Mesoscale Numerical Weather Prediction, Bound.-Lay. Meteorol., 132, 83, https://doi.org/10.1007/s10546-009-9388-0, 2009.

Pinty, J.-P. and Jabouille, P.: A mixed-phased cloud parameterization for use in a mesoscale non-hydrostatic model: Simulations of a squall line and of orographic precipitation, in: Preprints, Conf. on Cloud Physics, 217-220, Am. Meteorol. Soc., Everett, WA, USA, 1998.

Piriou, J.-M., Redelsperger, J.-L., Geleyn, J.-F., Lafore, J.-P., and Guichard, F.: An Approach for Convective Parameterization with Memory: Separating Microphysics and Transport in Grid-Scale Equations, J. Atmos. Sci., 64, 4127-4139, https://doi.org/10.1175/2007JAS2144.1, 2007.

Prein, A. F., Langhans, W., Fosser, G., Ferrone, A., Ban, N., Goergen, K., Keller, M., Tölle, M., Gutjahr, O., Feser, F., Brisson, E., Kollet, S., Schmidli, J., van Lipzig, N. P. M., and Leung, R.: A review on regional convection-permitting climate modeling: Demonstrations, prospects, and challenges, Rev. Geophys., 53, 323-361, https://doi.org/10.1002/2014RG000475, 2015.

Radu, R., Déqué, M., and Somot, S.: Spectral nudging in a spectral regional climate model, Tellus A: Dynam. Meteorol. Oceanogr., 60, 898-910, https://doi.org/10.1111/j.1600-0870.2008.00341.x, 2008.

Rae, J. G. L., Aðalgeirsdóttir, G., Edwards, T. L., Fettweis, X., Gregory, J. M., Hewitt, H. T., Lowe, J. A., Lucas-Picher, P., Mottram, R. H., Payne, A. J., Ridley, J. K., Shannon, S. R., van de Berg, W. J., van de Wal, R. S. W., and van den Broeke, M. R.: Greenland ice sheet surface mass balance: evaluating simulations and making projections with regional climate models, The Cryosphere, 6 , 1275-1294, https://doi.org/10.5194/tc-6-1275-2012, 2012.

Ricard, J. L. and Royer, J. F.: A Statistical Cloud Scheme For Use In An AGCM, Ann. Geophys. - Atmos. Hydro. Space Sci., 11, 1095-1115, 1993.

Riesco-Martín, J., Mora-García, M., de Pablo-Dávila, F., and Rivas-Soriano, L.: Regimes of intense precipitation in the Spanish Mediterranean area, Atmos. Res., 137, 66-79, https://doi.org/10.1016/j.atmosres.2013.09.010, 2014.

Rontu, L., Pietikäinen, J.-P., and Martin Perez, D.: Renewal of aerosol data for ALADIN-HIRLAM radiation parametrizations, Adv. Sci. Res., 16, 129-136, https://doi.org/10.5194/asr-16-1292019, 2019.

Rummukainen, M.: State-of-the-art with regional climate models, Wiley Interdisciplinary Reviews: Climate Change, 1, 82-96, https://doi.org/10.1002/wcc.8, 2010.

Santos-Burguete, C. (Ed.): La física del caos en la predicción meteorológica, AEMET, Ministerio para la Transición Ecológica, Madrid, Spain, 2018 (in Spanish).

Seity, Y., Brousseau, P., Malardel, S., Hello, G., Bénard, P., Bouttier, F., Lac, C., and Masson, V.: The AROME-France ConvectiveScale Operational Model, Mon. Weather Rev., 139, 976-991, https://doi.org/10.1175/2010MWR3425.1, 2011. 
Sevault, F., Somot, S., Alias, A., Dubois, C., Lebeaupin-Brossier, C., Nabat, P., Adloff, F., Déqué, M., and Decharme, B.: A fully coupled Mediterranean regional climate system model: design and evaluation of the ocean component for the 1980 2012 period, Tellus A: Dynam. Meteorol. Oceanogr., 66, 23967, https://doi.org/10.3402/tellusa.v66.23967, 2014.

Smith, R. N. B.: A scheme for predicting layer clouds and their water content in a general circulation model, Q. J. Roy. Meteorol. Soc., 116, 435-460, https://doi.org/10.1002/qj.49711649210, 1990.

SURFEX: SURFEX, available a: http://www.uerra.eu, last access: 18 March 2020.

Taylor, K. E., Stouffer, R. J., and Meehl, G. A.: An Overview of CMIP5 and the Experiment Design, B. Am. Meteorol. Soc., 93, 485-498, https://doi.org/10.1175/BAMS-D-11-00094.1, 2012.

Tedesco, M., Box, J. E., Cappelen, J., Fettweis, X., Mote, T. L., van de Wal, R. S. W., van den Broeke, M. R., Smeets, C. J. P. P., and Wahr, J.: Greenland Ice Sheet, in: State of the Climate in 2014, vol. 96 of Bulletin of the American Meteorological Society, 2015.

Tegen, I., Hollrig, P., Chin, M., Fung, I., Jacob, D., and Penner, J.: Contribution of different aerosol species to the global aerosol extinction optical thickness: Estimates from model results, J. Geophys. Res.-Atmos., 102, 23895-23915, https://doi.org/10.1029/97JD01864, 1997.

Teigen, R.: Numerical simulation of orographic precipitation in western Norway, Master's thesis, Geophysical Institute, University of Bergen, Bergen, Norway, available at: http://hdl.handle. net/1956/1296 (last access: 18 March 2020), 2005.

Temperton, C., Hortal, M., and Simmons, A.: A two-time-level semi-Lagrangian global spectral model, Q. J. Roy. Meteorol. Soc., 127, 111-127, 2001.

Termonia, P., Fischer, C., Bazile, E., Bouyssel, F., Brožková, R., Bénard, P., Bochenek, B., Degrauwe, D., Derková, M., El Khatib, R., Hamdi, R., Mašek, J., Pottier, P., Pristov, N., Seity, Y., Smolíková, P., Španiel, O., Tudor, M., Wang, Y., Wittmann, C., and Joly, A.: The ALADIN System and its canonical model configurations AROME CY41T1 and ALARO CY40T1, Geosci. Model Dev., 11, 257-281, https://doi.org/10.5194/gmd-11-2572018, 2018.
Toivonen, E., Hippi, M., Korhonen, H., Laaksonen, A., Kangas, M., and Pietikäinen, J.-P.: The road weather model RoadSurf (v6.60b) driven by the regional climate model HCLIM38: evaluation over Finland, Geosci. Model Dev., 12, 3481-3501, https://doi.org/10.5194/gmd-12-3481-2019, 2019.

van As, D., Fausto, R. S., Ahlstrøm, A. P., Andersen, S. B., Andersen, M. L., Citterio, M., Edelvang, K., Gravesen, P., Machguth, H., Nick, F. M., Nielsen, S., and Weidick, A.: Programme for Monitoring of the Greenland Ice Sheet (PROMICE): first temperature and ablation record, Geol. Surv. Denmark Greenland Bull., 23, 73-76, 2011.

van Meijgaard, E., van Ulft, L. H., Lenderink, G., De Roode, S. R., Wipfler, L., Boers, R., and Timmermans, R. M. A.: Refinement and application of a regional atmospheric model for climate scenario calculations of Western Europe, Tech. Rep. KvR 054/12, KNMI, available at: http://edepot.wur.n1/312258 (last access: 18 March 2020), 2012.

Voldoire, A., Decharme, B., Pianezze, J., Lebeaupin Brossier, C., Sevault, F., Seyfried, L., Garnier, V., Bielli, S., Valcke, S., Alias, A., Accensi, M., Ardhuin, F., Bouin, M.-N., Ducrocq, V., Faroux, S., Giordani, H., Léger, F., Marsaleix, P., Rainaud, R., Redelsperger, J.-L., Richard, E., and Riette, S.: SURFEX v8.0 interface with OASIS3-MCT to couple atmosphere with hydrology, ocean, waves and sea-ice models, from coastal to global scales, Geosci. Model Dev., 10, 4207-4227, https://doi.org/10.5194/gmd-10-4207-2017, 2017.

Wu, M., Nikulin, G., Kjellström, E., Belušić, D., Jones, C., and Lindstedt, D.: The impact of RCM formulation and resolution on simulated precipitation in Africa, Earth Syst. Dynam. Discuss., https://doi.org/10.5194/esd-2019-55, in review, 2019.

$\mathrm{Xu}$, K.-M. and Randall, D. A.: A Semiempirical Cloudiness Parameterization for Use in Climate Models, J. Atmos. Sci., 53, 3084-3102, https://doi.org/10.1175/15200469(1996)053<3084:ASCPFU>2.0.CO;2, 1996. 